https://helda.helsinki.fi

\title{
Perennial fallow strips support biological pest control in spring cereal in Northern Europe
}

\section{Toivonen, Marjaana}

2018-06

Toivonen, M , Huusela-Veistola , E \& Herzon , I 2018 , ' Perennial fallow strips support biological pest control in spring cereal in Northern Europe ', Biological Control , vol. 121, pp. 109-118 . https://doi.org/10.1016/j.biocontrol.2018.02.015

http://hdl.handle.net/10138/299126

https://doi.org/10.1016/j.biocontrol.2018.02.015

cc_by_nc_nd

acceptedVersion

Downloaded from Helda, University of Helsinki institutional repository.

This is an electronic reprint of the original article.

This reprint may differ from the original in pagination and typographic detail.

Please cite the original version. 


\section{Accepted Manuscript}

Perennial fallow strips support biological pest control in spring cereal in Northern Europe

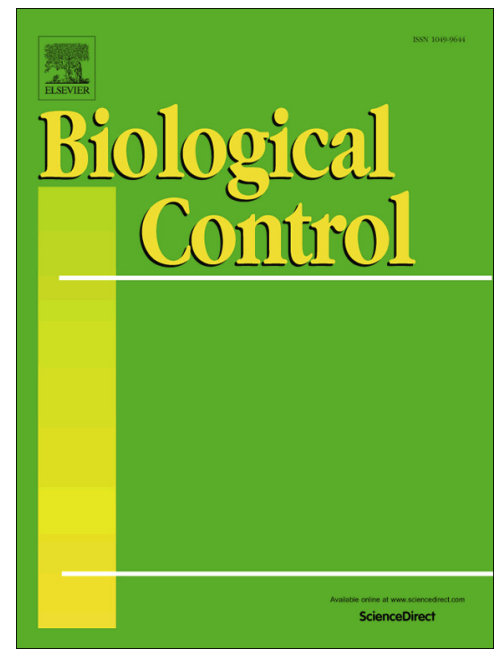

Marjaana Toivonen, Erja Huusela-Veistola, Irina Herzon

PII:

S1049-9644(18)30091-4

DOI: https://doi.org/10.1016/j.biocontrol.2018.02.015

Reference: YBCON 3724

To appear in:

\section{Biological Control}

Received Date: $\quad 28$ November 2017

Revised Date: $\quad 14$ February 2018

Accepted Date: $\quad 15$ February 2018

Please cite this article as: Toivonen, M., Huusela-Veistola, E., Herzon, I., Perennial fallow strips support biological pest control in spring cereal in Northern Europe, Biological Control (2018), doi: https://doi.org/10.1016/j.biocontrol. 2018.02.015

This is a PDF file of an unedited manuscript that has been accepted for publication. As a service to our customers we are providing this early version of the manuscript. The manuscript will undergo copyediting, typesetting, and review of the resulting proof before it is published in its final form. Please note that during the production process errors may be discovered which could affect the content, and all legal disclaimers that apply to the journal pertain. 
Perennial fallow strips support biological pest control in spring cereal in Northern Europe

Marjaana Toivonen $^{\text {a, b, } 1}$, Erja Huusela-Veistola ${ }^{c}$, Irina Herzon ${ }^{a}$

${ }^{a}$ Department of Agricultural Sciences, P.O. Box 27, FI-00014 University of Helsinki, Finland

${ }^{\mathrm{b}}$ Finnish Environment Institute (SYKE), Biodiversity Centre, P.O. Box 140, FI00251 Helsinki, Finland

${ }^{c}$ Natural Resources Institute Finland (Luke), Tietotie 4, FI-31600 Jokioinen, Finland

${ }^{1}$ Corresponding author: Marjaana Toivonen, Finnish Environment Institute, Biodiversity Centre, P.O. Box 140, FI-00251 Helsinki, Finland. Tel.: +358443488349. E-mail: marjaana.toivonen@ymparisto.fi

\section{Abstract}

Fallow strips are promoted through agri-climate-environment schemes to enhance farmland biodiversity, but their effects on biodiversity-mediated 
ecosystem services remain poorly studied in different cropping systems. The effects of fallow strips on biological control of bird cherry-oat aphids in spring barley were examined in a field experiment in Finland in 2014-2016. Two types of sown perennial fallow strips - grass strip and wildflower strip - were compared. The relative efficiency of biological pest control was tested by monitoring the number of experimentally added aphids in the fallow strips and in the adjacent barley fields at different distances from the strips. Data were also collected on the densities of naturally occurring aphids and ground-dwelling natural enemies. The effects of the fallow strips differed between years. When aphid pressure was high, the proximity of the strips slowed the growth of aphid population. In the year of low aphid abundance, the fallow strips sustained more aphids than the adjacent barley fields, but did not constitute a risk for pest control. In the second and third years, especially wildflower strips supported high activity density of ground-dwelling predators. The activity densities were particularly high in the both fallow strip types in early summer, highlighting the role of the perennial strips as refuges for natural enemies. The results suggest that perennial fallow strips, and especially those sown with diverse wildflower mixtures, can promote pest control in spring cereals, thus contributing to ecological intensification in agriculture.

Keywords: conservation biological control, habitat management, natural enemies, predatory arthropods, sown grass strip, sown wildflower strip 


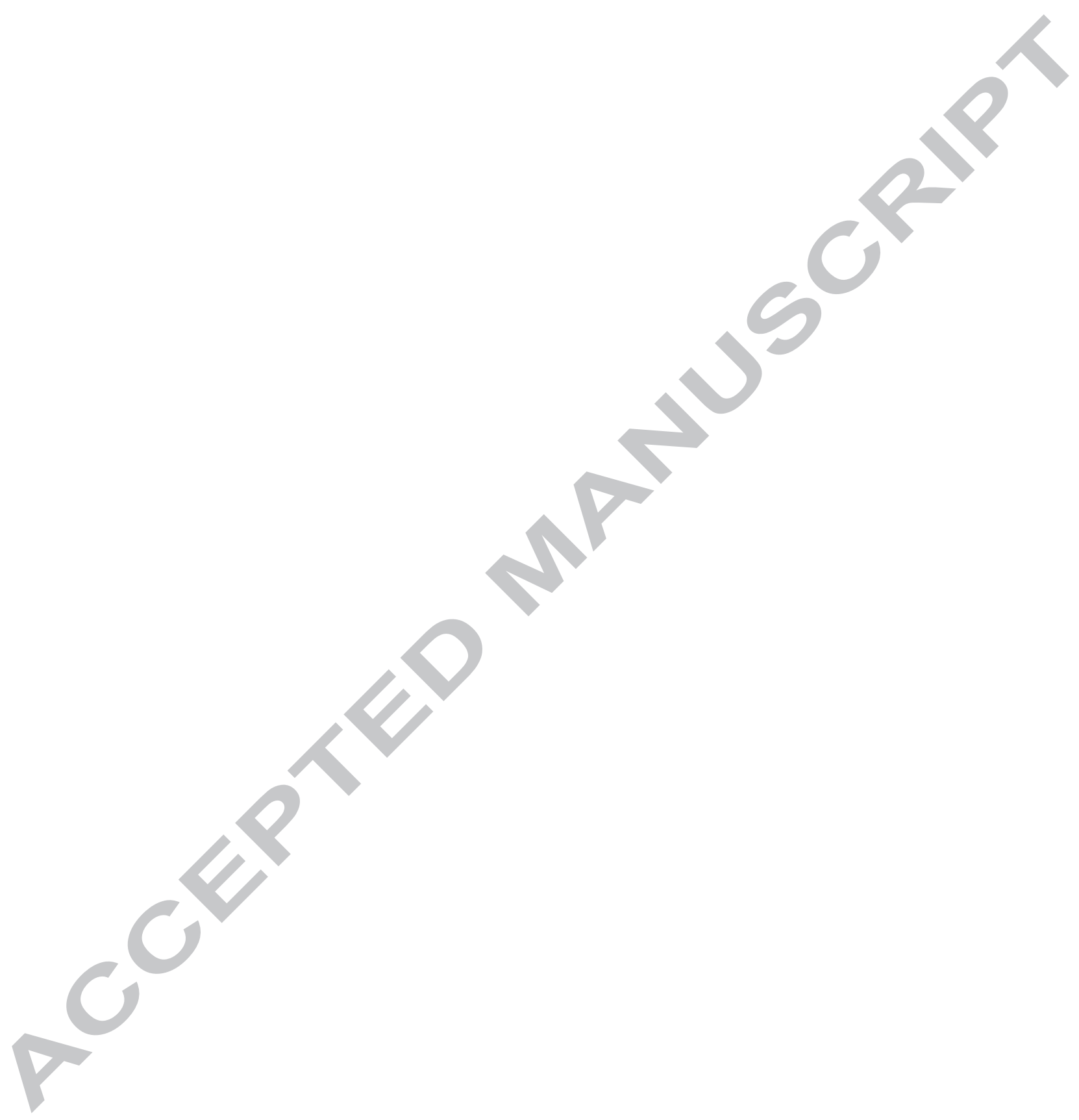




\section{Introduction}

Integrating ecosystem services management into agricultural systems has been proposed as a solution to meeting the growing demand for agricultural products while reducing dependency on anthropogenic inputs and minimizing negative environmental impacts (Bommarco et al., 2013; Doré et al., 2011; Tittonell, 2014). This approach, called as ecological intensification, is based on managing service-providing organisms that directly or indirectly contribute to crop production besides other ecosystem services (Bommarco et al., 2013; Tittonell, 2014). Although recent research has paid much attention to the concept and principles of ecological intensification (Bommarco et al., 2013; Doré et al., 2011; Tittonell, 2014), and provided empirical evidence on it (Holland et al., 2016; Letourneau et al., 2011; Pywell et al., 2015; Torralba et al., 2016; Tschumi et al., 2016a; Verret et al., 2017), the actual implementation of the approach is impeded by the lack of knowledge on the interventions needed to attain the desired level of ecosystem services in different crops and regions (Bommarco et al., 2013; Kremen and Miles, 2012; Duru et al., 2015; Westphal et al., 2015).

Biological pest control is a key ecosystem service for agriculture and an important part in integrated pest management (European Parliament and Council, 2009). In ecologically intensive cropping systems, pest control by 
naturally occurring enemies can be enhanced through targeted habitat management - an approach known as conservation biological control (Brewer and Elliott, 2004; Gurr et al., 2017; Holland et al., 2016; Tscharntke et al., 2007). One of the potential measures is the establishment of fallow strips in crop fields (Ramsden et al., 2015; Tschumi et al., 2015, 2016a, 2016b; Hatt et al., 2017). In Europe, different types of sown fallow strips and areas are promoted through agri-climate-environment schemes (Batáry et al., 2015; Haaland et al., 2011; Toivonen et al., 2013). Although fallow strips are usually targeted at biodiversity conservation, they can also effectively support natural enemies of crop pests (Haaland et al., 2011; Ramsden et al., 2015). Most often, fallow strips are established along field margins and sown with seed mixtures containing wildflowers ('wildflower strip') and grasses ('grass strip'), alone or in combination (Haaland et al., 2011). In Finland, an option of establishing so called 'biodiversity strips' with grass, wildflower, game or landscape seed mixtures along the field edges has become available for the present agriclimate-environment programming period of 2014-2020 (Ministry of Agriculture and Forestry, 2014).

The benefits of fallow strips for natural enemies are attributed to the stability and heterogeneity of these habitats compared to arable fields: perennial fallow strips provide natural enemies with alternative prey, overwintering places and refuge from disturbance, supporting the persistence of natural enemy 
populations (Landis et al., 2000; Bianchi et al., 2006). Wildflower strips provide also nectar and pollen, which serve as adult food for many carnivorous arthropods (Araj et al., 2011; Lu et al., 2014; Wäckers and van Rijn, 2012), and as additional larval food for some natural enemy species (Lundgren, 2009). Since plant species composition strongly affect resources available for natural enemies, informed selection of seed mixtures could greatly increase the benefits of fallow strips (Pontin et al., 2006; Wäckers and van Rijn, 2012). The selection of seed mixtures can be based on plant functional traits or, when available, demonstrated effects of plant species on natural enemies (Campbell et al., 2012; Wäckers and van Rijn, 2012).

Aphids (Hemiptera: Aphididae) are major pests of cereals in Europe (Vickerman and Wratten, 1979). In Scandinavian farmland with high percentage of spring-sown cereals, the most important species is bird cherry-oat aphid (Rhopalosiphum padi), the abundance of which varies greatly between years (Kurppa, 1990; Leather et al., 1989). The species overwinters as winter eggs on bird cherry trees (Prunus padus) and emigrates to a wide range of wild and cultivated grasses in spring and early summer, also transmitting barley yellow dwarf virus from wild grasses to cereals (Dixon, 1971; Leather et al., 1989). After establishment and fast growth phases, the field population crashes in the heading stage of cereals, when the species emigrates to wild grasses, before returning to bird cherry trees in autumn (Leather and Lehti, 1982). 
Generalist arthropod predators, including carabid beetles (Coleoptera:

Carabidae), rove beetles (Coleoptera: Staphylinidae) and spiders (Araneae), have been shown to reduce the abundance of bird cherry-oat aphids and to positively influence cereal yields (Helenius, 1990; Östman et al., 2003). As compared to specialist natural enemies such as parasitoids and syrphid flies, generalist natural enemies have an advantage in that they can be present in a field already when the pest arrives and thus prevent outbreaks (Symondson et al., 2002). However, the development of habitat management and farming practices that support generalist natural enemies and enhance conservation biological control in spring cereals have received little attention in research (but see Helenius et al., 1995; Huusela-Veistola, 1998; Östman et al., 2001).

This study experimentally examined the effects of two types of sown perennial fallow strips - wildflower strip and grass strip - on conservation biological control of bird cherry-oat aphids in spring barley. The first objective was to determine how the proximity of fallow strips affects the efficiency of biological pest control. The second objective was to analyze changes in the density and community composition of ground-dwelling natural enemies in the two fallow strip types and in the crop from a pest control perspective.

\section{Materials and methods}




\subsection{Study design}

The experiment was conducted in two fields in Helsinki, Southern Finland. One of the fields was situated in the research farm of the University of Helsinki $\left(60^{\circ} 22^{\prime} 50^{\prime \prime} \mathrm{N} 24^{\circ} 00^{\prime} 65^{\prime \prime} \mathrm{E}\right)$, and the other in the farm of the City of Helsinki $\left(60^{\circ} 26^{\prime} 61^{\prime \prime} \mathrm{N} 24^{\circ} 96^{\prime} 13^{\prime \prime E}\right)$. Soil types of the fields were loam and sandy clay. Spring barley was cultivated in both fields during three consecutive years in 2014-2016. No insecticides were applied in the fields during the three years, but herbicides were used in both fields to control weeds in barley (most commonly used herbicides Axial 50 EC, Eagle WG, Logran 20 WG and MCPA). In 2015, fungicide (Delaro SC 325) was sprayed in one of the fields.

In May 2014, two lines of fallow strips, each consisting of four contiguous 3-m wide and 60- $\mathrm{m}$ long fallow strips, were established $100 \mathrm{~m}$ apart in the both study fields (Fig. 1). The strips were not established along the field margins but in the middle of the fields in order to minimize the effects of permanent margins and surrounding landscape on the strips' flora and fauna. Two fallow strip types were included in the experiment: grass strip and wildflower strip. In each field, fallow type was randomly assigned to the first fallow strip. After that, fallow types were systematically allocated to the other strips so that every other fallow 
strip was sown with grass seed mixture and every other with wildflower mixture.

The grass seed mixture was a conventional grassland mixture used for fallows, containing Phleum pratense, Festuca pratensis, Festuca arundinacea and Lolium perenne (seed rates 11-14-3-3 $\mathrm{kg} \mathrm{ha}^{-1}$ respectively). The wildflower mixture contained a grass species Festuca trachyphylla $\left(7 \mathrm{~kg} \mathrm{ha}^{-1}\right)$, and annual and perennial flowering herbs that were selected to secure floral food supply for natural enemies: Achillea millefolium $\left(0.10 \mathrm{~kg} \mathrm{ha}^{-1}\right)$, Anethum graveolens $(0.17$ $\left.\mathrm{kg} \mathrm{ha}^{-1}\right)$, Borago officinalis $\left(0.20 \mathrm{~kg} \mathrm{ha}^{-1}\right)$, Carum carvi $\left(0.20 \mathrm{~kg} \mathrm{ha}^{-1}\right)$, Centaurea cyanus $\left(1.00 \mathrm{~kg} \mathrm{ha}^{-1}\right)$, Fagopyrum esculentum $\left(0.63 \mathrm{~kg} \mathrm{ha}^{-1}\right)$, Leucanthemum vulgare $\left(0.20 \mathrm{~kg} \mathrm{ha}^{-1}\right)$, Lotus corniculatus $\left(0.05 \mathrm{~kg} \mathrm{ha}^{-1}\right)$, Origanum vulgare $\left(0.03 \mathrm{~kg} \mathrm{ha}^{-1}\right)$, Pastinaca sativa $\left(0.30 \mathrm{~kg} \mathrm{ha}^{-1}\right)$, Phacelia tanacetifolia $\left(1.00 \mathrm{~kg} \mathrm{ha}^{-1}\right)$, Vicia sativa $\left(5.00 \mathrm{~kg} \mathrm{ha}^{-1}\right)$ and Vicia sepium $(0.05$ $\mathrm{kg} \mathrm{ha}^{-1}$ ) (Wäckers and van Rijn, 2012). Other criteria considered in the selection of plant species for the wildflower strips were early or long flowering period, importance to pollinator species, establishment success, and seed cost. Information on these criteria came from seed producers. Fallow strips were mowed in early August 2014 and 2015 and cuttings were left on the strips.

\#Fig. 1 here\# 


\subsection{Biological control of aphids}

The efficiency of biological pest control in the fallow strips and the adjacent barley fields was tested in 2015 and 2016, i.e. the second and third years after the establishment of the strips. Bird cherry-oat aphids were brought into the fallow strips and the barley fields at several distances from the strips using potted barley plants (method 1) and sticker paper (method 2).

In the method 1, barley pots were prepared by growing three barley plants in 1.5-liter plastic pots. At tillering stage, each plant was infested with 4 wingless bird cherry-oat aphids of mixed age (nymphs and adults), resulting in 12 aphids per pot. When aphids had settled and were feeding, their number was checked, and if changed, extra aphids were removed or new aphids added. After the checking, the pots were moved to the study fields where barley was at the same growth stage than in the pots. One pot was placed in the middle of each fallow strip and five pots in the barley field between two opposite strips at 6, 12 and 50-m distances from the edges of the strips (Fig. 1). The pots were buried in the ground to allow ground-dwelling predators to access the plants. In 2015, the barley pots were moved to the experiment on 10 June, and the number of aphids in the pots was recorded daily until 15 June. In 2016, the monitoring was continued two days longer, from 2 until 9 June, because the number of aphids kept increasing (Fig. 2). Potted plants were used to standardize the 
measurements: the pots had the same soil type, were planted with the same barley variety, were grown in the same conditions before moving to the experiment, and were infested with aphids from the same population. Mean temperature during the experiment was $13^{\circ} \mathrm{C}$ in 2015 , with daily means ranging from 12 to $15^{\circ} \mathrm{C}$. In 2016 , mean temperature was $14{ }^{\circ} \mathrm{C}$, with daily means between 10 and $20^{\circ} \mathrm{C}$. Total precipitation during the experiment was 10 and $11 \mathrm{~mm}$, in 2015 and 2016, respectively.

In the method 2, four live bird cherry-oat aphids were placed on small pieces $(1.5 \times 2.0 \mathrm{~cm})$ of white sticker paper (APLI PAPER S.A.U., Spain). The aphids were gently pushed against the paper to make sure that both their body and legs got stuck on the paper. The papers were anchored to the ground by a map-pin (the method used in Östman, 2004). One paper piece was placed in the middle of each fallow strip and five papers in the barley field between two opposite strips similarly to potted barley plants. Remaining aphids were counted after 24 hours. No natural enemies were stuck on the papers, but legs and other remnants of aphids on the papers confirmed predator attacks. The papers were set out on 11 June 2015 and 2 June 2016.

The two complementary methods were assumed to provide adequate data to estimate relative efficiency of biological pest control among the fallow strips and the adjacent fields. Bird cherry-oat aphids on potted barley plants 
represented normal prey for natural enemies. The method also allowed to monitor the changes in aphid population over several days. However, the causes of aphid population decrease or increase on potted plants couldn't be confirmed, because aphids could move freely. Sedentary aphids on sticker papers were probably not as attractive to predators as free-living aphids, but the advantage of the method was that the disappearance of the aphids could be only due to predation.

In addition, the abundance of naturally occurring aphids was recorded in the barley fields at 6,12 and 50-m distances from the fallow strips three times between the end of May and mid-July at approximately three week intervals. Ten barley tillers were selected at random along a 5-m long transect running parallel to the fallow strip. On each tiller all cereal aphids and mummified aphids were recorded. Since the incidence of mummified aphids was very low, they were not included in statistical analyses. Besides bird cherry-oat aphids, the total number of cereal aphids included a low number of grain aphids (Sitobion avenae) in the latest counts in July.

\subsection{Predator monitoring}

Predatory arthropods on the soil surface were sampled with pitfall traps in 2014-2016. Plastic cups (87-mm diameter and 58-mm deep) were filled with 
saturated $\mathrm{NaCl}$ solution and detergent. One pitfall trap was placed at the middle of each fallow strip and one trap in the adjacent barley field at 6-m distance from the strip. The traps were covered with transparent plastic roofs to prevent flooding during rainfall. The pitfall traps were installed around two weeks after the sowing of barley, on 27 May 2014, 2 June 2015 and 25 May 2016, and emptied every seven days for eight weeks. The catches were stored in $70 \%$ alcohol. Predatory arthropods were identified to family. Ground beetles, the most abundant predator group in the catches, were further sorted into genera.

\subsection{Fallow strip vegetation}

Vegetation composition of the fallow strips was surveyed in 2014-2016. The coverage of individual plant species and bare ground in the area of $3 \times 10 \mathrm{~m}$ in the middle of each fallow strip were estimated using a 9-grade logarithmic scale $(1=0-0.125 \%, 2=0.125-0.5 \%, 3=0.5-2 \%, 4=2-4 \%, 5=4-8 \%, 6=8-16 \%$, $7=16-32 \%, 8=32-64 \%, 9=64-100 \%$ ) (Raatikainen et al., 2007). Vegetation height was measured in ten systematically spaced spots in the survey area by setting a measurement stick vertically into the vegetation and reading the measurement from the highest point where the vegetation touched the stick. Vascular plants were identified to species except for Taraxacum sp., and two sown fescue species in grass strips, $F$. pratensis and $F$. arundinacea, which 
were treated as one species. The vegetation survey was conducted once per year, between the end of June and mid-July.

\subsection{Statistical analyses}

The effects of the fallow strips on the number of aphids (experimentally added aphids on potted barley plants and on sticker papers, and naturally occurring aphids in crop) and natural enemies were analyzed with generalized linear mixed models (GLMMs) using the function glmer of the R package lme4 (Bates et al., 2014). Since the response variables were counts of aphids and natural enemies, Poisson distribution was used in the GLMMs. Fixed factor in the models was the position of the measurements (barley pots, sticker papers, aphid monitoring transects and pitfall traps) in the study fields in relation to fallow strips: wildflower strip, grass strip, and 6,12 and 50-m distances from the strips. The study fields were divided into four sections consisting of the pairs of opposite fallow strips (grass strip and wildflower strip) and the crop between them (Fig. 1). The fields and the sections of the fields were included as nested random effects in the GLMMs to account for other effects of geographical location than that arising from the location in relation to the two fallow strip types. 
For experimentally added aphids, the number of aphids in the end of the experiment was used as a response variable, and models were fitted separately for each year. For naturally occurring aphids, the response variable was the number of aphids per ten barley tillers, and the abundance was modelled separately for two first counts in 2016. In 2015 and at the last count in 2016, the abundance of naturally occurring aphids was not modelled because incidence of aphids was very low. For natural enemies, one model was fitted for each year with eight sampling weeks, and the sampling points were included as a nested random effect with the fields and the sections of the fields.

All the models were tested by using likelihood ratio tests. To compare each treatment (i.e. position in relation to fallow strips) with one another, Tukey's post-hoc pairwise comparisons were done using the glht function of the $\mathrm{R}$ package multcomp (Hothorn et al. 2008). All analyses were done using the statistical programme R version 3.0.2 (R Core Team, 2013).

\section{Results}

\subsection{The abundance of naturally occurring aphids}

The abundance of naturally occurring aphids in barley differed considerably between the years 2015 and 2016. In 2015, the density of bird cherry-oat aphids 
was low. In the study fields, $0.03 \pm 0.13$ aphid per barley tiller were recorded in early June, and $0.18 \pm 0.37$ in late June. In 2016, $20 \pm 12$ aphids per barley tiller were recorded in the end of May, and 32 \pm 37 in mid-June.

The proximity of the fallow strips affected the abundance of naturally occurring aphids in barley in 2016, a year of high aphid infestation (30 May: $\mathrm{X}^{2}=103.99$, $\mathrm{df}=4, \mathrm{p}<0.001 ; 20$ June: $\left.\mathrm{X}^{2}=221.14, \mathrm{df}=4, \mathrm{p}<0.001\right)$. In the end of May, aphids were more abundant in the middle of barley fields than at 6 or $12-\mathrm{m}$ distances from the fallow strips (Fig. 2, Table 1). Three weeks later in mid-June, aphids were the most abundant close to grass strips and the least abundant close to wildflower strips (Fig. 2, Table 1). In the last count in mid-July, barley was in the heading stage, and aphid density was very low in every part of the fields (Fig. 2).

\#Fig. 2 here\#

\#Table 1 here\#

\subsection{Effects of fallow strips on biological control of aphids}

Experimentally added bird cherry-oat aphids on potted barley plants showed contrasting trends in abundance between the two years: In 2015, the number of 
aphids decreased during the monitoring period, apart from the pots placed in the fallow strips, where aphid numbers remained relatively stable (Fig. 3). In 2016, the number of aphids substantially increased in the barley pots during the experiment (Fig. 3). The increase was slowest in the fallow strips and fastest in the pots placed furthest from the strips in barley (Fig. 3). In both years, the position of the barley pot in relation to the fallow strips affected the number of aphids in the end of the monitoring period (2015: $X^{2}=137.64, d f=6, p<0.001$; 2016: $\left.X^{2}=4091.50, d f=6, p<0.001\right)$. Differences between the fallow strips and the barley fields were statistically significant in both years (Table 2). In 2016, significant differences were found also between different positions in barley (Table 2).

\#Fig. 3 here\#

\#Table 2 here\#

The removal rate of bird cherry-oat aphids from sticker papers was higher in 2015 than in 2016: on average, $1.4 \pm 1.4$ and $0.8 \pm 1.2$ aphids out of 4 disappeared in 2015 and 2016, respectively. The position in relation to the two fallow strip types didn't explain statistically significantly the number of aphids on the papers $\left(2015: X^{2}=11.48, d f=6, p=0.07 ; 2016: X^{2}=8.06, d f=6, p=0.23\right)$. 
However, there was a trend of more aphids left on papers in the barley fields than in the fallow strips (Table 3).

\#Table 3 here\#

\subsection{Activity density of ground-dwelling predators}

Differences in the number of aphidophagous predators between the pitfall traps placed in different positions in relation to fallow strips were found in all three years $\left(2014: X^{2}=27.17, d f=3, p<0.001 ; 2015: X^{2}=9.26, d f=3, p=0.026 ; 2016\right.$ : $\left.X^{2}=18.68, d f=3, p<0.001\right)$. The number of predators was significantly higher in the wildflower strips than in the barley fields in every summer, whereas the grass strips had higher predator numbers than the barley fields only in 2014 and 2016 (Table 4), No significant differences were found between the two fallow strip types (Table 4).

During the first summer 2014, the number of aphidophagous predators in the pitfall traps increased in the fallow strips (Fig. 4). In the second and third years, natural enemy catches were particularly high in the fallow strips in early season (Fig. 4). After mid-June, weekly fluctuation in natural enemy catches increased, and differences between the fallow strips and the barley fields became less clear (Fig. 4). 
\#Table 4 here\#

\#Fig. 4 here\#

The most abundant families of natural enemies in the pitfall trap catches were Carabidae (10851 individuals during three years), Linyphiidae (6306), Staphylinidae (2739), Lycosidae (2197), Coccinellidae (1316) and Araneidae (486). The most abundant genus of Carabidae were Pterostichus (5738), Harpalus (2396), Trechus (1194) and Bembidion (731).

In 2014, the numbers of Carabidae and Staphylinidae were higher in both fallow strip types than in the barley fields (Fig. 5, Table A.1). In the following years, the highest numbers of Carabidae and Staphylinidae were found in the wildflower strips (Fig. 5, Table A.1). For Lycosidae and Araneidae, difference between the fallow strips and the barley fields increased over years: both spider groups peaked in the third year in the fallow strips (Fig. 5, Table A.1). The number of Linyphiidae in the pitfall catches remained relatively stable over the three years (Fig. 5), and no differences were found between the fallow strips and the barley fields (Table A.1). The number of Coccinellidae fluctuated between years (Fig. 5). In 2016, i.e. the year of high aphid abundance, more 
Coccinellidae were found in the barley fields than in the fallow strips (Fig. 5, Table A.1).

\#Fig. 5 here\#

\subsection{Vegetation of the fallow strips}

The two fallow strip types differed in their vegetation composition and structure (Table 5, Table A.2): Wildflower strips had higher plant species richness and lower cover of grasses than grass strips. In the first summer 2014, wildflower strips had higher and denser swards than grass strips due to annual herbs in the wildflower seed mixture. However, the development of perennial vegetation was slower in wildflower strips than in grass strips, resulting in lower and sparser swards in the second summer. In the third summer 2016, the both strip types had dense vegetation.

\#Table 5 here\#

\section{Discussion}

4.1 The effects of fallow strips' proximity on biological control of bird cherryoat aphids 
Our results suggest that sown perennial fallow strips can enhance biological control of bird cherry-oat aphids in spring cereal: Firstly, the proximity of the fallow strips slowed aphid population increase in the year of high aphid abundance. Secondly, the inverse trends of ground-dwelling predators in the fallow strips and the barley fields before the peak of aphid infestation suggest a move of predators from the fallow strips to the fields. However, the fallow strips did not prevent aphid numbers from rising far above the action threshold for pesticide application of one aphid per five plants in tillering stage used in Finland (Markkula and Huusela-Veistola, 2012). If relying on chemical pesticides is not possible, as is in organic farming, fallow strips provide an alternative method to alleviate pest pressure and damage to crops but may not be sufficient to prevent it entirely (Tschumi et al., 2016a, 2016b; Hatt et al., 2017).

The density of naturally occurring bird cherry-oat aphids differed between the two years when aphids were experimentally added to the fields. In 2015, aphid density was low, whereas, in 2016, abundant winter eggs (Natural Resources Institute Finland, 2016) combined with exceptionally warm May (Finnish Meteorological Institute, 2016) enhanced early and abundant colonization of bird cherry-oat aphids in spring cereals. In both years, changes in aphid densities in the potted barley plants were smaller in fallow strips than in the 
adjacent barley fields. Interestingly, when aphid density was low, the fallow strips seemed to provide more suitable habitat for aphids than the barley fields despite the trend of higher predation rate in the strips, demonstrated by the experiment with sticker papers. Sown and wild grasses in the fallow strips can potentially host bird cherry-oat aphids (Leather and Dixon, 1982). In addition, fallow strips may provide favorable microclimate: in early summer, perennial swards maintain more constant temperature and humidity than sparser cereal stands (Wiktelius, 1987). Although the fallow strips maintained higher aphid numbers than the barley fields in the year of low aphid abundance, aphid populations did not increase. Furthermore, the proximity of the strips did not increase aphid numbers in the barley fields. Thus, the fallow strips did not constitute a source of aphids and a risk for pest control, but rather supported pest control by providing prey for predators.

Previous studies on the impacts of fallow strips on pest control have focused on wildflower strips (Pfiffner et al., 2009; Tschumi et al., 2015, 2016a, 2016b), although grass strips are also known to promote natural enemies (HuuselaVeistola, 1998; Sarthou et al., 2014; Woodcock et al., 2008). The effects of the two fallow strip types on pest control have not previously been compared in a field experiment. However, a recent study comparing permanent grass margins with simple, sown flower strips suggested effective control of aphids in fields with either type of margin (Mansion-Vaquié et al., 2017). In order for 
wildflower strips to be the preferred by farmers, they should provide clear additional benefits compared to grass strips, which have lower seed cost and good establishment and persistence of sown vegetation in field soils. Based on our results, wildflower strips may reduce aphid pressure in spring cereal better than grass strips: the activity density of ground-dwelling predators was higher in the perennial wildflower strips, and the abundance of naturally occurring aphids remained lower close to the wildflower strips. However, when considering changes in the number of experimentally added aphids, the differences between the strip types were not clear.

The density of naturally occurring aphids in the barley fields may be influenced by the fallow strips also through other mechanisms than predation: especially wildflower strips with abundant forbs may represent an unattractive habitat for cereal aphids, thus acting similarly to intercrops, i.e. making adjacent cereal resources harder to locate and slowing down the spread of aphids within the field (Trenbath, 1993; Schröder et al., 2014). The only sown grass species in the wildflower strips, $F$. trachyphylla, may also be unattractive for bird cherry-oat aphids, since it morphologically resembles $F$. ovina and $F$. rubra, which the aphid has been reported to avoid as a host (Leather and Dixon, 1982). By contrast, L. perenne included in the grass strip mixture may attract the aphid (ibid.) In previous studies, flower abundance and diversity in wildflower strips have been found to be positively related to natural enemy abundance (Haenke et 
al., 2009; Ramsden et al., 2015) and crop yield (Tschumi et al., 2016a), which also supports the idea of the higher benefits of wildflower strips than grass strips. However, more experiments under realistic field conditions are necessary in order to identify the mechanisms driving the effects of fallow strips on biological pest control.

\subsection{Predator communities in fallow strips and in adjacent crop from a pest} control perspective

The results of pitfall trapping showed differences in the development of natural enemy communities between the fallow strip types, reflecting differences in vegetation composition and structure (Denys and Tscharntke, 2002; Frank et al., 2009; Woodcock et al., 2005). In the establishment year, differences between the fallow strip types were small. In the second and third years, especially wildflower strips supported high activity density of carabid beetles and rove beetles. For rove beetles, the result is consistent with Sarthou et al. (2014) reporting that managed fallow strips dominated by dicotyledonous plants were better source habitat of rove beetles in spring than grass-dominated strips, while the abundance of carabid beetles and spiders didn't differ between the fallow strip types. In general, epigeal predators are likely to be less influenced by plant species composition than flying natural enemies such as parasitoids and hoverflies, which are dependent on floral nectar, besides other resource 
requirements (Gillespie et al., 2016; Wäckers and van Rijn, 2012; van Rijn and Wäckers, 2016). Despite the differences in the density and species composition of ground-dwelling predators between the perennial fallow strip types in our study, the peak of predator activity density both in wildflower and grass strips in early summer of the second and third years suggests the importance of the both strip types as overwintering habitats and refuges from disturbance for the natural enemies (Frank and Reichhart, 2004; Pfiffner and Luka, 2000; Ramsden et al., 2015).

The pitfall trap catches included a small number of carabid beetles that were not aphid predators. The second most abundant carabid genus in the pitfall traps, Harpalus, comprises omnivorous and phytophagous species (Lindroth, 1986). The most abundant species of the genus was $H$. rufipes, which feeds on both plant seeds and insects, including cereal aphids (Jørgensen and Toft, 1997). Since carabid beetles were mostly identified at genus level only, all species regardless of their feeding habits were included in the analyses.

Pitfall traps mostly catch epigeal predators foraging on the soil surface. However, coccinellids, which consisted mainly of Coccinella septempunctata, were also trapped, although they usually forage on plants. Coccinella septempunctata is a specialist natural enemy whose abundances follow the within-season development of aphid populations with a time lag (Leather and 
Lehti, 1982). Besides feeding on aphids, coccinellids and other foliar-foraging predators such as syrphid fly larvae may enhance the predation rate of epigeal predators by getting aphids to fall from the vegetation to the ground or to linyphiid webs (Losey and Denno, 1998).

Not all natural enemies present in the fallow strips may have contributed equally to biological pest control in the adjacent fields: despite the substantial increase of Lycosidae and Araneidae spiders in the fallow strips over three years, the abundance of these spiders remained low at 6-m distance from the strips. Spiders have been reported to show a low preference to $R$. padi, possibly due to a deterrent or toxic substances in the aphids (Toft, 1995). Thus, fallow strips might provide spiders with alternative, higher ranking prey. In addition, Lycosids and Araneids may be more susceptible to intensive cultivation than the other studied natural enemy groups, thus favoring permanent habitats (Duelli et al., 1990; Glück and Ingrisch, 1990; Huusela-Veistola, 1998; Pfiffner and Luka, 2003).

In general, efficient movement between semi-natural habitats and cultivated fields is more typical for carabid beetles and rove beetles than for spiders (Duelli et al., 1990). In the United Kingdom, studies on the spring emigration of carabid beetles from beetle banks led to a recommendation that these habitats should be spaced at least $100 \mathrm{~m}$ apart (Landis et al., 2000). However, the 
positive effects of fallow strips on pest control may be restricted to a much shorter distance from the strips than $50 \mathrm{~m}$ (Tschumi et al., 2016a). Combining fallow strips with other management methods that enhance diversity within fields, such as companion plants (Balmer et al., 2013), intercropping (Lopes et al., 2016; Trenbath, 1993), conservation agriculture (Tamburini et al., 2016; Chabert and Sarthou, 2017) or abstaining from chemical control (Holzschuh et al., 2010; Pfiffner and Luka, 2003), could further attract natural enemies from fallow strips into cultivated fields, while also reducing pest abundance through other mechanisms.

\section{Conclusions}

Perennial fallow strips have potential to support biological pest control in intensively cultivated agricultural landscapes by diversifying resource availability for generalist natural enemies, and, through this, possibly also by contributing to the reduction of pesticide use. The positive effects of fallow strips on pest regulation are at least partly due to predation by natural enemies, but may also be influenced by other ecological mechanisms. Our results suggest that especially diverse wildflower strips may alleviate pest outbreaks in spring cereals, besides promoting biodiversity. This functional role of the non-crop strips is still poorly understood and appreciated by farmers who worry about weed infestations and economic losses (Cordeau et al., 2011), and establish 
voluntary fallows mainly for reasons of convenience, subsidy or game management (Birge, 2017). The observed differences between the years in the effects of the fallow strips highlight the need for long-term studies in order to find the best methods to compose habitats to enhance biological pest control. Finally, research into the effect of the biological pest control on the realized yield and economic profit across years of varied pest abundance is necessary in order to evaluate the measure's cost-effectiveness in spring cereals.

\section{Acknowledgements}

We thank Meri Saarnia, Wenfei Liao and Bakhan Taimouri for helping with field work and data management. We are grateful to Viikki Research Farm and Haltiala Farm who provided field parcels for the experiment, and to the technical staff of the University of Helsinki who helped with the establishment and management of the experiment. We also acknowledge Felix Wäckers and Eve Veromann for sharing their expertise and experiences in biological control experiments, and Jarno and Riitta Mäki from AhonAlku for sharing their expertise in designing wildflower seed mixture. This work was supported by the Doctoral programme in the Sustainable Use of Renewable Natural Resources of the University of Helsinki, Jenny and Antti Wihuri Foundation, and August Johannes and Aino Tiura Agricultural Research Foundation. We also thank anonymous reviewers for helpful comments on the manuscript. 


\section{References}

Araj, S., Wratten, S., Lister, A., Buckley, H., Ghabeish, I. (2011) Searching behaviour of an aphid parasitoid and its hyperparasitoid with and without floral nectar. Biol. Control, 57, 79-84.

Balmer, O., Pfiffner, L., Schied, J., Willareth, M., Leimgruber, A., Luka, H., Traugott, M. (2013) Noncrop flowering plants restore top-down herbivore control in agricultural fields. Ecol. Evol., 3, 2634-2646.

Batáry, P., Dicks, L.V., Kleijn, D., Sutherland, W.J. (2015) The role of agrienvironment schemes in conservation and environmental management. Conserv. Biol., 29, 1006-1016.

Bates, D., Maechler, M., Bolker, B., Walker, S. (2014) lme4: Linear mixedeffects models using Eigen and S4. R package, version 1.1-7.

Bianchi, F.J.J.A., Booij, C.J.H., Tscharntke, T. (2006) Sustainable pest regulation in agricultural landscapes: a review on landscape composition, biodiversity and natural pest control. P. Roy. Soc. B Biol. Sci., 273, 1715-1727. 
Birge, T. (2017) The nature of farmers: farm-level decision making for farmland conservation targets. Doctoral thesis, University of Helsinki. Department of Agricultural Sciences Publications 48, Helsinki. http://urn.fi/URN:ISBN:1798-744X

Bommarco, R., Kleijn, D.,Potts, S.G. (2013) Ecological intensification: harnessing ecosystem services for food security. Trends Ecol. Evol., 28, 230238.

Brewer, M.J., Elliott, N.C. (2004) Biological control of cereal aphids in North America and mediating effects of host plant and habitat manipulations. Annu. Rev. Entomol., 49, 219-42.

Campbell, A.J., Biesmeijer, J.C., Varma, V., Wäckers, F.L., (2012) Realising multiple ecosystem services based on the response of three beneficial insect groups to floral traits and trait diversity. Basic Appl. Ecol., 13, 363-370.

Chabert, A., Sarthou, J.-P. (2017) Practices of conservation agriculture prevail over cropping systems and landscape heterogeneity in understanding the ecosystem service of aphid biocontrol. Agr. Ecosyst. Environ., 249, 70-79. 
Cordeau, S., Reboud, X., Chauvel, B. (2011) Farmers' fears and agro-economic evaluation of sown grass strips in France. Agron. Sustain. Dev., 31, 463-473.

Denys, C., Tscharntke, T. (2002) Plant-insect communities and predator-prey ratios in field margin strips, adjacent crop fields, and fallows. Oecologia, 130, $315-324$.

Dixon, A.F.G. (1971) The life-cycle and host preferences of the bird cherry-oat aphid, Rhopalosiphum padi L., and their bearing on the theories of host alternation in aphids. Ann. Appl. Biol., 68, 135-147.

Doré, T., Makowski, D., Malézieux, E., Munier-Jolain, N., Tchamitchian, M., Tittonell, P. (2011) Facing up to the paradigm of ecological intensification in agronomy: Revisiting methods, concepts and knowledge. Eur. J. Agron., 34, $197-210$.

Duelli, P., Studer, M., Marchand, I., Jakob, S. (1990) Population movements of arthropods between natural and cultivated areas. Biol. Conserv., 54, 193-207.

Duru, M., Therond, O., Martin, G., Martin-Clouaire, R., Magne, M.-A., Justes, E., Journet, E.-P., Aubertot, J.-N., Savary, S., Bergez, J.-E., Sarthou, J.-P. 
(2015) How to implement biodiversity-based agriculture to enhance ecosystem services: a review. Agron. Sustain. Dev., 35, 1259-1281.

European Parliament and Council (2009) Directive 2009/128/EC of the European Parliament and of the Council on establishing a framework for Community action to achieve the sustainable use of pesticides, art. 3. O.J. L 309/71. http://eur-lex.europa.eu/legalcontent/EN/TXT/PDF/?uri=CELEX:32009L0128\&from=EN

Finnish Meteorological Institute (2016) Temperature and precipitation statistics from 1961 onwards. http://en.ilmatieteenlaitos.fi/statistics-from-1961-onwards

Frank, T., Aeschbacher, S., Barone, M., Künzle, I., Lethmayer, C., Mosimann, C. (2009) Beneficial arthropods respond differentially to wildflower areas of different age. Ann. Zool. Fenn., 46, 465-480.

Frank, T., Reichhart, B. (2004) Staphylinidae and Carabidae overwintering in wheat and sown wildflower areas of different age. B. Entomol. Res., 94, 209217. 
Gillespie, M.A., Gurr, G.M., Wratten, S.D. (2016) Beyond nectar provision: the other resource requirements of parasitoid biological control agents. Entomol. Exp. Appl., 159, 207-221.

Glück, E. Ingrisch, S. (1990) The effect of bio-dynamic and conventional agriculture management on Erigoninae and Lycosidae spiders. J. Appl. Entomol., 110, 13-148.

Gurr, G.M., Wratten, S.D., Landis, D.A., You, M.-S. (2017) Habitat management to suppress pest populations: progress and prospects. Annu. Rev. Entomol., 62, 91-109.

Haaland, C., Naisbit, R.E., Bersier, L.-F. (2011) Sown wildflower strips for insect conservation: a review. Insect Conserv. Diver., 4, 60-80.

Haenke, S., Scheid, B., Schaefer, M., Tscharntke, T., Thies, C. (2009) Increasing syrphid fly diversity and density in sown flower strips within simple vs complex landscapes. J. Appl. Ecol., 46, 1106-1114. 
Hatt, S., Lopes, T., Boeraeve, F., Che, J., Francis, F. (2017) Pest regulation and support of natural enemies in agriculture: Experimental evidence of within field wildflower strips. Ecol. Eng., 98, 240-245.

Helenius, J. (1990) Effect of epigeal predators on infestation by the aphid Rhopalosiphum padi and on grain yield of oats in monocrops and mixed intercrops. Entomol. Exp. Appl., 54, 225-236.

Helenius, J., Holopainen, J., Muhojoki, M., Pokki, P., Tolonen, T., Venäläinen, A. (1995) Effect of undersowing and green manuring on abundance of ground beetles (Coleoptera, Carabidae) in cereals. Acta Zool. Fenn., 196, 156-159.

Holland, J.M., Bianchi, F.J.J.A., Entling, M.H., Moonen, A.C., Smith, B.M., Jeanneret, P. (2016) Structure, function and management of semi-natural habitats for conservation biological control: a review of European studies. Pest Manag. Sci., 72, 1638-1651.

Holzschuh, A., Steffan-Dewenter, I., Tscharntke, T. (2010) How do landscape composition and configuration, organic farming and fallow strips affect the diversity of bees, wasps and their parasitoids? J. Anim. Ecol., 79, 491-500. 
Hothorn, T., Bretz, F., Westfall, P. (2008) Simultaneous inference in general parametric models. Biometrical J., 50, 346-363.

Huusela-Veistola, E. (1998) Effects of perennial grass strips on spiders (Araneae) in cereal fields and impact on pesticide side-effects. J. Appl. Entomol., 122, 575-583.

Jørgensen, H.B., Toft, S. (1997) Food preference, diet dependent fecundity and larval development in Harpalus rufipes (Coleoptera: Carabidae). Pedobiologia, $41,307-315$.

Kremen, C., Miles, A. (2012) Ecosystem services in biologically diversified versus conventional farming systems: Benefits, externalities, and trade-offs. Ecol. Soc., 17, 40.

Kurppa, S. (1990) Insect pest damage, predicting and control in Finnish cereal cultivation during the 1980s. Doctoral thesis, University of Helsinki. Vammalan kirjapaino Oy, Vammala.

Landis, D., Wratten, S., Gurr, G. (2000) Habitat management to conserve natural enemies of arthropod pests in agriculture. Annu. Rev. Entomol., 45, $175-201$. 
Leather, S.R., Dixon, A.F.G. (1982) Secondary host preferences and reproductive activity of the bird cherry-oat aphid, Rhopalosiphum padi. Ann. Appl. Biol., 101, 219-228.

Leather, S.R., Lehti, J.P. (1982) Field studies on the factors affecting the population dynamics of the bird cherry-oat aphid, Rhopalosiphum padi (L.) in Finland. Ann. Agr. Fenn., 21, 20-31.

Leather, S.R., Walters, K.F.A, Dixon A.F.G (1989) Factors determining the pest status of the bird cherry-oat aphid, Rhopalosiphum padi (L.) (Hemiptera: Aphididae), in Europe: a study and review. B. Entomol. Res., 79, 345-360.

Letourneau, D.K., Armbrecht, I., Rivera, B.S., Lerma, J.M., Carmona, E.J., Daza, M.C., Escobar, S., Galindo, V., Gutiérrez, C., López, S.D., Mejía, J.L., Rangel, A.M.A., Rangel, J.H., Rivera, L., Saavedra, C.A., Torres, A.M., Trujillo, A.R. (2011) Does plant diversity benefit agroecosystems? A synthetic review. Ecol. Appl., 21, 9-21.

Lindroth, C.H. (1986) The Carabidae (Coleoptera) of Fennoscandia and Denmark. Fauna Entomologica Scandinavica 15, part 2. Scandinavian Science Press Ltd., Leiden/Copenhagen. 
Lopes, T., Hatt, S., Xu, Q., Chen, J., Liu, Y., Francis, F. (2016) Wheat (Triticum aestivum L.)-based intercropping systems for biological pest control: a review. Pest Manag. Sci., 72, 2193-2202.

Losey, J.E., Denno, R.F. (1998) Positive predator-predator interactions: enhanced predation rates and synergistic suppression of aphid populations. Ecology, 79, 2143-2152.

Lu, Z.-X., Zhu, P.-Y., Gurr, G.M., Zheng, X.-S., Read, D.M.Y., Heong, K.-L., Yang, Y.-J.,Xu, H.-X. (2014) Mechanisms for flowering plants to benefit arthropod natural enemies of insect pests: prospects for enhanced use in agriculture. Insect Sci., 21, 1-12.

Lundgren, J.G. (2009) Nutritional aspects of non-prey foods in the life histories of predaceous Coccinellidae. Biol. Control, 51, 294-305.

Mansion-Vaquié, A., Ferrante, M., Cook, S.M., Pell, J.K., Lövei, G.L. (2017) Manipulating field margins to increase predation intensity in fields of winter wheat (Triticum aestivum). J. Appl. Entomol., 141, 600-611. 
Markkula, I., Huusela-Veistola, E. (2012) Viljat. Kevätviljat. Tuhoeläimet. In: Ahvenniemi, P. (Ed.), Ajankohtaisia kasvinsuojeluohjeita (Current guidelines in plant protection). Kasvinsuojeluseuran julkaisuja 103, Kasvinsuojeluseura ry, Hämeenlinna, pp. 56-61.

Ministry of Agriculture and Forestry (2014) Rural development programme for mainland

Finland 2014-2020. https://www.maaseutu.fi/globalassets/rural_fi/ruralprogram/rural_development_programme_2014-2020.pdf

Natural Resources Institute Finland (2016) Tuomikirvaennuste 2016 (Bird cherry-oat aphid forecast 2016)

https://portal.mtt.fi/portal/page/portal/kasper/pelto/peltopalvelut/tuomikirvaennu $\underline{\text { ste/vanhattuomikirvaennusteet }}$

Östman, Ö. (2004) The relative effects of natural enemy abundance and alternative prey abundance on aphid predation rates. Biol. Control, 30, 281-287.

Östman, Ö., Ekbom, B., Bengtsson, J. (2001) Landscape heterogeneity and farming practice influence biological control. Basic Appl. Ecol., 2, 365-371. 
Östman, Ö., Ekbom, B., Bengtsson, J. (2003) Yield increase attributable to aphid predation by ground-living polyphagous natural enemies in spring barley in Sweden. Ecol. Econ., 45, 149-158.

Pfiffner, L., Luka, H. (2000) Overwintering of arthropods in soils of arable fields and adjacent semi-natural habitats. Agr. Ecosyst. Environ., 78, 215-222.

Pfiffner, L., Luka, H. (2003) Effects of low-input farming systems on carabids and epigeal spiders - a paired farm approach. Basic Appl. Ecol., 4, 117-127.

Pfiffner, L., Luka, H., Schlatter, C., Juen, A., Traugott, M. (2009) Impact of wildflower strips on biological control of cabbage lepidopterans. Agr. Ecosyst. Environ., 129, 310-314.

Pontin, D., Wade, M, Kehrli, P., Wratten, S. (2006) Attractiveness of single and multiple species flower patches to beneficial insects in agroecosystems. Ann.

Appl. Biol., 148, 39-47.

Pywell, R.F., Heard, M.S., Woodcock, B.A., Hinsley, S., Ridding, L., Nowakowski, M., Bullock, J.M. (2015) Wildlife-friendly farming increases crop yield: evidence for ecological intensification. P. Roy. Soc. B Biol. Sci., 282, 20151740. 
Raatikainen, K.M., Heikkinen. R.K., Pykälä, J. (2007) Impacts of local and regional factors on vegetation of boreal semi-natural grasslands. Plant Ecol., $189,155-173$.

Ramsden M.W., Menéndez R., Leather S.R., Wäckers F. (2015) Optimizing field margins for biocontrol services: The relative role of aphid abundance, annual floral resources, and overwinter habitat in enhancing aphid natural enemies. Agr. Ecosyst. Environ., 199, 94-104.

R Core Team (2013) R: A language and environment for statistical computing. R Foundation for Statistical Computing, Vienna, Austria.

Sarthou, J.-P., Badoz, A., Vaissière, B., Chevallier, A., Rusch, A. (2014) Local more than landscape parameters structure natural enemy communities during their overwintering in semi-natural habitats. Agr. Ecosyst. Environ., 194, 17-28.

Schröder, M.L., Glinwood, R., Ignell, R., Krüger, K. (2014) Visual cues and host-plant preference of the bird cherry-oat aphid, Rhopalosiphum padi (Hemiptera: Aphididae). African Entomol., 22, 428-436. 
Symondson, W.O., Sunderland, K.D., Greenstone, M.H. (2002) Can generalist predators be effective biocontrol agents? Annu. Rev. Entomol., 47, 561-94.

Tamburini, G., De Simone, S., Sigura, M., Boscutti, F., Marini, L. (2016) Conservation tillage mitigates the negative effect of landscape simplification on biological control. J. Appl. Ecol., 53, 233-241.

Tittonell, P. (2014) Ecological intensification of agriculture — sustainable by nature. Curr. Opin. Env. Sust., 8, 53-61.

Toft, S. (1995) Value of the aphid Rhopalosiphum padi as food for cereal spiders. J. Appl. Ecol., 32, 552-560.

Toivonen, M., Herzon, I., Helenius, J. (2013) Environmental Fallows as a new policy tool to safeguard farmland biodiversity in Finland. Biol. Conserv., 159, $355-366$.

Torralba, M., Fagerholm, N., Burgess, P.J.,Moreno, G., Plieninger, T. (2016)

Do European agroforestry systems enhance biodiversity and ecosystem services? A meta-analysis. Agr. Ecosyst. Environ., 230, 150-161. 
Trenbath, B.R. (1993) Intercropping for the management of pests and diseases.

Field Crop Res., 34, 381-405.

Tscharntke T., Bommarco R., Clough Y., Crist T.O., Kleijn D., Rand T.A., Tylianakis J.M., van Nouhuys S., Vidal S. (2007) Conservation biological control and enemy diversity on a landscape scale. Biol. Control, 43, 294-309.

Tschumi, M.L.U., Albrecht, M., Bärtschi, C., Collatz, J., Entling, M.H., Jacot, K. (2016a) Perennial, species-rich wildflower strips enhance pest control and crop yield. Agr. Ecosyst. Environ., 220, 103-97.

Tschumi, M., Albrecht, M., Collatz, J., Dubsky, V., Entling, M.H., NajarRodriguez, A.J., Jacot, K., Kleijn, D. (2016b) Tailored flower strips promote natural enemy biodiversity and pest control in potato crops. J. Appl. Ecol., 53, $1169-1176$.

Tschumi, M., Albrecht, M., Entling, M.H., Jacot, K. (2015) High effectiveness of tailored flower strips in reducing pests and crop plant damage. P. Roy. Soc. B Biol. Sci., 282, 20151369.

Wäckers, F., van Rijn, P. (2012) Pick and mix: selecting flowering plants to meet the requirements of target biological control insects. In: Gurr, G. et al. 
(Eds.). Biodiversity and Insect Pests: Key Issues for Sustainable Management. John Wiley \& Sons, Ltd.

van Rijn, P.C., Wäckers, F.L. (2016) Nectar accessibility determines fitness, flower choice and abundance of hoverflies that provide natural pest control. J. Appl. Ecol., 53, 925-933.

Verret, V., Gardarin, A., Pelzer, E., Médiène, S., Makowski, D., ValantinMorison, M. (2017) Can legume companion plants control weeds without decreasing crop yield? A meta-analysis. Field Crop Res., 204, 158-168.

Westphal, C., Vidal, S., Horgan, F.G., Gurr, G.M., Escalada, M., Van Chien, H., Tscharntke, T., Heong, K.L., Settele, J. (2015) Promoting multiple ecosystem services with flower strips and participatory approaches in rice production landscapes. Basic Appl. Ecol., 16, 681-689.

Vickerman, G.P., Wratten, S.D. (1979) The biology and pest status of cereal aphids (Hemiptera: Aphididae) in Europe: a review. Bull. Entomol. Res., 69, 1-32.

Wiktelius, S. (1987) Distribution of Rhopalosiphum padi (Hornoptera: Aphididae) on spring barley plants. Ann. Appl. Biol., 110, 1-7. 
Woodcock, B.A., Westbury, D.B., Potts, S.G., Harris, S.J., Brown, V.K. (2005)

Establishing field margins to promote beetle conservation in arable farms. Agr. Ecosyst. Environ., 107, 255-266.

Woodcock, B.A., Westbury, D.B., Tscheulin, T., Harrison-Cripps, J., Harris, S.J., Ramsey, A.J., Brown, V.K., Potts, S.G. (2008) Effects of seed mixture and management on beetle assemblages of arable field margins. Agr. Ecosyst.

Environ., 125, 246-254. 


\section{Table captions}

Table 1. Results of Tukey's pairwise post-hoc tests comparing the number of naturally occurring aphids in barley $(n=40)$ in different positions in relation to two fallow strip types. The first column shows the positions to which the positions of the second column were compared to. Aphids were counted from ten barley tillers at 6,12 and 50-m distances from two types of fallow strips. Separate models were fitted for the first and the second count in 2016. The last count in mid-July is not included in the table, because aphid density was very low (Fig. 2), and no differences between the positions in relation to fallow strips were observed.

Table 2. Results of Tukey's pairwise post-hoc tests comparing the number of bird cherry-oat aphids in the end of the monitoring period on potted barley plants $(\mathrm{n}=56)$ in different positions in relation to two fallow strip types. The first column shows the positions to which the positions of the second column were compared to. Years 2015 and 2016 were analyzed separately.

Table 3. Results of Tukey's pairwise post-hoc tests comparing the number of bird cherry-oat aphids left on sticker papers $(\mathrm{n}=56)$ after 24 hours in different positions in relation to two fallow strip types. The first column shows the 
positions to which the positions of the second column were compared to. Years 2015 and 2016 were analyzed separately.

Table 4. Results of Tukey's pairwise post-hoc tests comparing the number of ground dwelling predatory arthropods in pitfall traps $(n=32)$ placed in two types of fallow strips and at 6-m distance from the strips in barley field. The first column shows the positions to which the positions of the second column were compared to. Years 2014-2016 were analyzed separately.

Table 5. Vegetation characteristics (mean \pm SD) of the studied fallow strips in 2014-2016. The fallow strips were established in May 2014. 
Table 1

\begin{tabular}{|c|c|c|c|c|c|c|c|c|c|}
\hline \multirow[t]{2}{*}{ Factor levels } & & \multicolumn{4}{|l|}{30 May } & \multicolumn{4}{|l|}{20 June } \\
\hline & & \multicolumn{2}{|l|}{ Estimat } & \multicolumn{2}{|l|}{ Z- } & \multicolumn{2}{|l|}{ Estimat } & \\
\hline Wildflower & Wildflower & & 0.0 & & & & 0.0 & & \\
\hline \multirow[t]{5}{*}{$6 \mathrm{~m}$} & $12 \mathrm{~m}$ & 0.02 & 4 & 0.47 & ns & -0.07 & 3 & -2.44 & ns \\
\hline & Grass $6 \mathrm{~m}$ & -0.02 & $\begin{array}{l}0.0 \\
4\end{array}$ & -0.44 & ns & 0.29 & $\begin{array}{l}0.0 \\
3\end{array}$ & 10.35 & $*$ \\
\hline & Grass $12 \mathrm{~m}$ & -003 & $\begin{array}{l}0.0 \\
4\end{array}$ & -084 & ns & 020 & 3 & 695 & $\begin{array}{l}* * \\
*\end{array}$ \\
\hline & Both types & & 0.0 & & $* *$ & & 0.0 & & $* *$ \\
\hline & $50 \mathrm{~m}$ & 0.26 & 3 & 7.65 & $*$ & 0.17 & 3 & 5.99 & $*$ \\
\hline \multirow{5}{*}{$\begin{array}{l}\text { Wildflower } \\
12 \mathrm{~m}\end{array}$} & Grass $6 \mathrm{~m}$ & & 0.0 & & & & 0.0 & & $* *$ \\
\hline & & -0.03 & 4 & -0.90 & ns & 0.36 & 3 & 12.73 & $*$ \\
\hline & Grass $12 \mathrm{~m}$ & -0.05 & $\begin{array}{l}0.0 \\
4\end{array}$ & -1.31 & ns & 0.27 & $\begin{array}{l}0.0 \\
3\end{array}$ & 9.36 & $\begin{array}{l}* * \\
*\end{array}$ \\
\hline & Both types & & 0.0 & & $* *$ & & 0.0 & & $* *$ \\
\hline & $50 \mathrm{~m}$ & 0.24 & 3 & 7.19 & $*$ & 0.25 & 3 & 8.41 & $*$ \\
\hline \multirow[t]{3}{*}{ Grass $6 \mathrm{~m}$} & Grass $12 \mathrm{~m}$ & & $\begin{array}{l}0.0 \\
4\end{array}$ & -0.40 & ns & -0.09 & $\begin{array}{l}0.0 \\
3\end{array}$ & -3.44 & $* *$ \\
\hline & Both types & & 0.0 & & $* *$ & & 0.0 & & $* *$ \\
\hline & $50 \mathrm{~m}$ & 28 & 3 & 8.08 & $*$ & -0.12 & 3 & -4.40 & $*$ \\
\hline \multirow{2}{*}{ Grass $12 \mathrm{~m}$} & Both $t$ & & 0.0 & & $* *$ & & 0.0 & & \\
\hline & $50 \mathrm{~m}$ & 0.29 & 3 & 8.47 & $*$ & -0.03 & 3 & -0.96 & ns \\
\hline
\end{tabular}
$* \mathrm{p}<0.05, * * \mathrm{p}<0.01, * * * \mathrm{p}<0.001$ 
Table 2

\section{Factor}

levels

$$
2015 \quad 2016
$$

\begin{tabular}{|c|c|c|c|c|c|c|c|c|c|}
\hline & & $\begin{array}{l}\text { Estimat } \\
\mathrm{e}\end{array}$ & SE & $\begin{array}{l}\text { z- } \\
\text { value }\end{array}$ & $\mathrm{p}$ & $\begin{array}{l}\text { Estimat } \\
\mathrm{e}\end{array}$ & $\mathrm{SE}$ & $\begin{array}{l}\text { z- } \\
\text { value }\end{array}$ & \\
\hline \multirow{11}{*}{ Wildflower } & Grass & & 0.1 & & & & 0.0 & & \\
\hline & Giass & 0.17 & 6 & 1.10 & ns & -0.14 & 5 & -2.63 & ns \\
\hline & Wildflower & & 0.2 & & & & 0.0 & & $* *$ \\
\hline & $6 \mathrm{~m}$ & -1.10 & 3 & -4.78 & $* * *$ & 1.18 & 4 & 28.03 & $*$ \\
\hline & Wildflower & & 0.2 & & & & 0.0 & & $* *$ \\
\hline & $12 \mathrm{~m}$ & -1.27 & 5 & -5.18 & $* * *$ & 1.38 & 4 & 33.65 & $*$ \\
\hline & Grass $6 \mathrm{~m}$ & -1.23 & $\begin{array}{l}0.2 \\
4\end{array}$ & -5.08 & $* * *$ & 1.31 & $\begin{array}{l}0.0 \\
4\end{array}$ & 33.46 & $\begin{array}{l}* * \\
*\end{array}$ \\
\hline & Grass $12 \mathrm{~m}$ & & 0.2 & & & & 0.0 & & $* *$ \\
\hline & & -1.61 & 8 & -5.72 & $* * *$ & 1.39 & 4 & 33.87 & $*$ \\
\hline & Both types & & 0.2 & 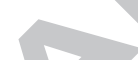 & & & 0.0 & & $* *$ \\
\hline & $50 \mathrm{~m}$ & -1.68 & 9 & -5.79 & $* * *$ & 1.52 & 4 & 37.63 & $*$ \\
\hline \multirow{8}{*}{ Grass } & Wildflower & & 0.2 & 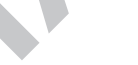 & & & 0.0 & & $* *$ \\
\hline & $6 \mathrm{~m}$ & -1.27 & 3 & -5.64 & $* * *$ & 1.32 & 4 & 29.72 & $*$ \\
\hline & Wildflower & & 0.2 & & & & 0.0 & & ** \\
\hline & $12 \mathrm{~m}$ & & 4 & -5.98 & $* * *$ & 1.52 & 4 & 35.03 & $*$ \\
\hline & & & $\begin{array}{l}0.2 \\
4\end{array}$ & -5.90 & $* * *$ & 1.52 & $\begin{array}{l}0.0 \\
4\end{array}$ & 34.85 & $\begin{array}{l}* * \\
*\end{array}$ \\
\hline & Grass $12 \mathrm{~m}$ & & 0.2 & & & & 0.0 & & $* *$ \\
\hline & Both types & -1.78 & $\begin{array}{l}8 \\
0.2\end{array}$ & -6.41 & $* * *$ & 1.53 & $\begin{array}{l}4 \\
0.0\end{array}$ & 35.24 & $\begin{array}{l}* \\
* *\end{array}$ \\
\hline & $50 \mathrm{~m}$ & -1.85 & 9 & -6.46 & $* * *$ & 1.67 & 4 & 38.78 & $*$ \\
\hline \multirow[t]{7}{*}{ Wildflower } & Wildflower & & 0.2 & & & & 0.0 & & $* *$ \\
\hline & $12 \mathrm{~m}$ & -0.17 & 9 & -0.59 & ns & 0.20 & 3 & 7.46 & $*$ \\
\hline & Grass $6 \mathrm{~m}$ & -0.13 & $\begin{array}{l}0.2 \\
9\end{array}$ & -0.44 & ns & 0.20 & $\begin{array}{l}0.0 \\
3\end{array}$ & 7.20 & $\begin{array}{l}* * \\
*\end{array}$ \\
\hline & Grass $12 \mathrm{~m}$ & & 0.3 & & & & 0.0 & & $* *$ \\
\hline & Grass $12 \mathrm{ml}$ & -0.51 & 3 & -1.57 & ns & 0.21 & 3 & 7.77 & * \\
\hline & Both types & & 0.3 & & & & 0.0 & & $* *$ \\
\hline & $50 \mathrm{~m}$ & -0.58 & 3 & -1.75 & ns & 0.35 & 3 & 13.05 & $*$ \\
\hline \multirow{5}{*}{$\begin{array}{l}\text { Wildflower } \\
12 \mathrm{~m}\end{array}$} & Grass $6 \mathrm{~m}$ & & 0.3 & & & & 0.0 & & \\
\hline & & 0.05 & $\begin{array}{l}0 \\
03\end{array}$ & 0.15 & ns & -0.01 & $\begin{array}{l}3 \\
00\end{array}$ & -0.26 & ns \\
\hline & Grass $12 \mathrm{~m}$ & -0.34 & 4 & -1.00 & ns & 0.01 & 3 & 0.31 & $\mathrm{~ns}$ \\
\hline & Both types & & 0.3 & & & & 0.0 & & $* *$ \\
\hline & $50 \mathrm{~m}$ & -0.41 & 4 & -1.18 & ns & 0.14 & 3 & 5.68 & $*$ \\
\hline Grass & Grass $12 n$ & -0.38 & 0.3 & -1.15 & ns & 0.01 & 0.0 & 0.57 & ns \\
\hline
\end{tabular}




\begin{tabular}{rllllllllll} 
& & \multicolumn{3}{c}{3} & & & & 3 & & \\
& Both types & & 0.3 & & & & 0.0 & & $* *$ \\
& $50 \mathrm{~m}$ & -0.45 & 4 & -1.33 & $\mathrm{~ns}$ & 0.15 & 3 & 5.94 & $*$ \\
\multirow{2}{*}{ Grass $12 \mathrm{~m}$} & Both types & & 0.3 & & & & 0.0 & & $* *$ \\
& $50 \mathrm{~m}$ & -0.07 & 7 & -0.19 & $\mathrm{~ns}$ & 0.13 & 3 & 5.37 & $*$ \\
\hline$* \mathrm{p}<0.05, * * \mathrm{p}<0.01, * * * \mathrm{p}<0.001$ & & & & & & &
\end{tabular}


Table 3

\begin{tabular}{|c|c|c|c|c|c|c|c|c|c|}
\hline \multirow{2}{*}{ Factor levels } & & \multicolumn{4}{|l|}{2015} & \multicolumn{4}{|l|}{2016} \\
\hline & & \multicolumn{2}{|l|}{ Estimat } & $\begin{array}{l}\text { z- } \\
\text { value }\end{array}$ & & \multicolumn{2}{|l|}{ Estimat } & \\
\hline & & & & & & & NL & valt & \\
\hline \multirow{9}{*}{ Wildflower } & & & 0.3 & & & & 0.3 & & \\
\hline & Grass & 0.37 & 9 & 0.96 & ns & 0.16 & 3 & 0.49 & ns \\
\hline & Wildflower & & 0.3 & & & & 0.3 & & \\
\hline & $6 \mathrm{~m}$ & 0.90 & 6 & 2.51 & ns & 0.57 & 0 & 1.87 & ns \\
\hline & Wildflower & & 0.3 & & & 30 & 0. & & \\
\hline & $12 \mathrm{~m}$ & 0.90 & 6 & 2.51 & ns & 39 & 1 & 1.23 & ns \\
\hline & Grass $6 \mathrm{~m}$ & 0.78 & $\begin{array}{l}0.3 \\
6\end{array}$ & 2.14 & & & $\begin{array}{l}0.3 \\
0\end{array}$ & 1.99 & ns \\
\hline & Grass $12 \mathrm{~m}$ & 0.49 & $\begin{array}{l}0.3 \\
8\end{array}$ & 1.29 & ns & 0.5 & $\begin{array}{l}0.3 \\
0\end{array}$ & 1.87 & ns \\
\hline & $\begin{array}{l}\text { Both types } \\
50 \mathrm{~m}\end{array}$ & 0.78 & $\begin{array}{l}0.3 \\
6\end{array}$ & 2.14 & ns & 0.60 & $\begin{array}{l}0.3 \\
0\end{array}$ & 1.99 & ns \\
\hline
\end{tabular}

Grass

Wildflower

$6 \mathrm{~m}$

$\begin{array}{lllll}0.52 & 2 & 1.66 & & \\ & & 0.41\end{array}$

0.2

Wildflower

$12 \mathrm{~m}$

0.3

$\begin{array}{lll}9 & 1.41 \quad \mathrm{~ns}\end{array}$

Grass $6 \mathrm{~m}$

$\begin{array}{lllll}0.52 & 2 & 1.66 & & \\ & & & 0.22\end{array}$

0.3

$\begin{array}{lll}0 & 0.74 & \text { ns }\end{array}$

Grass $6 \mathrm{~m}$ 0.3

Grass $12 \mathrm{~m}$

$\begin{array}{lllll}0.41 & 2 & 1.26 & \text { ns } & 0.44\end{array}$

0.2

Both types

$50 \mathrm{~m}$

0.3

$\begin{array}{lllll}0.12 & 4 & 0.34 & \text { ns } & 0.41\end{array}$

$\begin{array}{lll}9 & 1.53 \mathrm{~ns}\end{array}$

0.2

$9 \quad 1.41$ ns

Wildflower 6 Wildflower $\mathrm{m}$

$12 \mathrm{~m}$

Grass 6 m

0.3

$0.3 \quad 0.44$

0.2

$\begin{array}{lllllll}0.41 & 2 & 1.26 & \mathrm{~ns} & 9 & 1.53 & \mathrm{~ns}\end{array}$ 0.2

0.2

$\begin{array}{llllllll}0.00 & 7 & 0.00 & \mathrm{~ns}^{-0.18} & 7 & -0.67 & \mathrm{~ns}\end{array}$

Grass 6 m

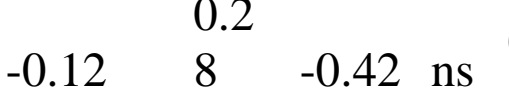

0.2

Grass $12 \mathrm{~m}$

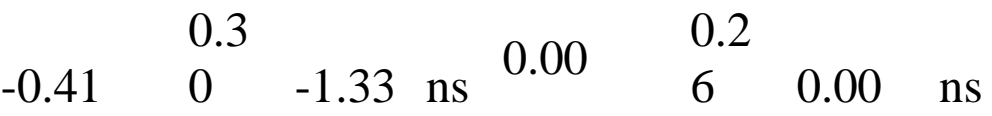

Both types

$50 \mathrm{~m}$

Wildflower $12 \mathrm{~m}$

Grass $6 \mathrm{~m}$

0.2
8

0.2

$\begin{array}{lll}6 & 0.13 & \mathrm{~ns}\end{array}$

0.2

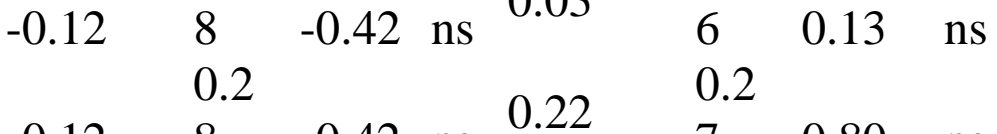

Grass $12 \mathrm{~m}$

$\begin{array}{lll}8 & -0.42 \mathrm{~ns}\end{array}$

0.3

Both types

$50 \mathrm{~m}$

$\begin{array}{llll}-0.41 & 0 & -1.33 \mathrm{~ns}\end{array}$

0.18

0.2

$0.80 \mathrm{~ns}$

0.2

$\begin{array}{lllll}-0.12 & 8 & -0.42 & \text { ns } & 0.22\end{array}$

$\begin{array}{lll}7 & 0.67 & \mathrm{~ns}\end{array}$

0.2

$\begin{array}{lll}7 & 0.80 & \text { ns }\end{array}$

Grass $6 \mathrm{~m} \quad$ Grass $12 \mathrm{~m}$

$\begin{array}{lll}0.3 & 0.2\end{array}$

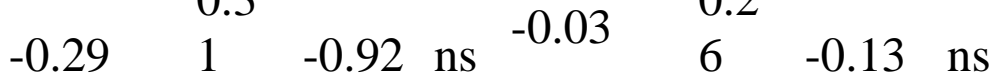




\begin{tabular}{|c|c|c|c|c|c|c|c|c|c|}
\hline \multirow{4}{*}{ Grass $12 \mathrm{~m}$} & Both types & & 0.2 & & & \multirow{2}{*}{0.00} & 0.2 & \multirow[b]{2}{*}{0.00} & \\
\hline & $50 \mathrm{~m}$ & 0.00 & 9 & 0.00 & ns & & 5 & & ns \\
\hline & Both types & & 0.3 & & & & 0.2 & & \\
\hline & $50 \mathrm{~m}$ & 0.29 & 1 & 0.92 & ns & 0.03 & 6 & 0.13 & ns \\
\hline
\end{tabular}


Table 4

\begin{tabular}{|c|c|c|c|c|c|}
\hline \multirow[t]{2}{*}{ Factor level } & & \multicolumn{4}{|l|}{2014} \\
\hline & & Estimate & SE & $\begin{array}{l}\text { z- } \\
\text { value }\end{array}$ & $\mathrm{p}$ \\
\hline \multirow[t]{4}{*}{ Wildflower } & Grass & 0.14 & 0.11 & 1.23 & $\mathrm{~ns}$ \\
\hline & Wildflower & & & & \\
\hline & $6 \mathrm{~m}$ & -0.48 & 0.11 & -4.30 & $* * *$ \\
\hline & $\begin{array}{l}\text { Grass } 6 \mathrm{~m} \\
\text { Wildflower }\end{array}$ & -0.41 & 0.11 & -3.66 & $* *$ \\
\hline \multirow[t]{2}{*}{ Grass } & $6 \mathrm{~m}$ & -0.62 & 0.11 & -5.53 & $* * *$ \\
\hline & Grass $6 \mathrm{~m}$ & -0.54 & 0.11 & -4.88 & $* * *$ \\
\hline
\end{tabular}

Wildflower

\begin{tabular}{llllll}
$6 \mathrm{~m}$ & Grass $6 \mathrm{~m}$ & 0.07 & 0.11 & 0.65 & $\mathrm{~ns}$ \\
\hline & & 2015
\end{tabular}

Z-

Estimate SE value $p$

$\begin{array}{llllll} & \text { Wildflower Grass } & -0.27 & 0.15 & -1.77 & \text { ns }\end{array}$

Wildflower

$\begin{array}{llll}6 \mathrm{~m} & -0.45 & 0.15 & -2.95\end{array}$

Grass $6 \mathrm{~m} \quad-0.42 \quad 0.15-2.75 \quad *$

Wildflower

$\begin{array}{llllll}\text { Grass } & 6 \mathrm{~m} & -0.18 & 0.15 & -1.18 & \mathrm{~ns} \\ & \text { Grass } 6 \mathrm{~m} & -0.15 & 0.15 & -0.98 & \mathrm{~ns}\end{array}$

Wildflower

\begin{tabular}{llllll}
$6 \mathrm{~m}$ & Grass 6 m & 0.03 & 0.15 & 0.19 & $\mathrm{~ns}$ \\
\hline & 2016 & & \\
\hline & & \multicolumn{5}{c}{$\mathrm{z}^{-}$}
\end{tabular}

$\begin{array}{llll}\text { Estimate } & \text { SE } & \text { value } & p \\ -0.20 & 0.13 & -1.63 & \mathrm{~ns}\end{array}$

\begin{tabular}{lllllll}
\hline Wildflower & Grass & -0.20 & 0.13 & -1.63 & $\mathrm{~ns}$ \\
& Wildflower & & & & \\
& $6 \mathrm{~m}$ & -0.50 & 0.13 & -4.01 & $* * *$ \\
& Grass 6 m & -0.59 & 0.13 & -4.67 & $* *$ \\
& Wildflower & & & & \\
Grass & $6 \mathrm{~m}$ & -0.30 & 0.13 & -2.38 & $\mathrm{~ns}$ \\
& Grass 6 m & -0.39 & 0.13 & -3.05 & $*$
\end{tabular}

Wildflower

\begin{tabular}{llrrrr}
$6 \mathrm{~m}$ & Grass $6 \mathrm{~m}$ & -0.09 & 0.13 & $-0.67 \quad \mathrm{~ns}$ \\
\hline$* \mathrm{p}<0.05, * * \mathrm{p}<0.01, * * * \mathrm{p}<0.001$ & &
\end{tabular} 
Table 5

\begin{tabular}{|c|c|c|c|c|c|c|}
\hline & \multicolumn{3}{|c|}{ Wildflower strip (n=8) } & \multicolumn{3}{|c|}{ Grass strip $(n=8)$} \\
\hline & 2014 & 2015 & 2016 & 2014 & 2015 & 2016 \\
\hline $\begin{array}{l}\text { Plant species } \\
\text { richness }\end{array}$ & $22 \pm 2$ & $19 \pm 2$ & $15 \pm 3$ & $18 \pm 4$ & $15 \pm 5$ & 1 \\
\hline $\begin{array}{l}\text { Vegetation height } \\
(\mathrm{cm})\end{array}$ & $52 \pm 24$ & $41 \pm 19$ & $45 \pm 9$ & $27 \pm 11$ & $68 \pm 16$ & $83 \pm 14$ \\
\hline Grasses (\%) & $6 \pm 7$ & $43 \pm 36$ & $79 \pm 20$ & $40 \pm 40$ & $89 \pm 23$ & $88 \pm 18$ \\
\hline Bare ground $(\%)$ & $4.4 \pm 5.0$ & $8.1 \pm 8.6$ & $0 \pm 0$ & $12.9 \pm 11.4$ & $1.3 \pm 3.3$ & $0.1 \pm 0.4$ \\
\hline
\end{tabular}




\section{Figure captions}

Fig. 1. Two experimental barley fields in Helsinki, Finland. Two lines of green fallow strips, each consisting of four 3-m wide 60-m long strips, were established in both fields in May 2014. Fallow strips were sown with grass seed mixture (black) and wildflower mixture (gray). Efficiency of biological pest control was tested in the fallow strips and in the barley fields at five positions between the opposite strips (6 m, $12 \mathrm{~m}$ and $50 \mathrm{~m}$ from both strip types), which is illustrated with white dots. For the statistical analyses, the study fields were divided into four sections consisting of the pairs of opposite fallow strips and the crop between them, which is illustrated with dash lines.

Fig. 2. Mean numbers of naturally occurring aphids in barley tillers at 6, 12 and 50-m distances from two types of fallow strips $(\mathrm{W}=$ wildflower strip, $\mathrm{G}=$ grass strip) in 2016. W/G $50 \mathrm{~m}$ indicate the position in the middle of the barley field at 50-m distance from both fallow strip types. Error bars indicate \pm one standard error.

Fig. 3. Mean numbers of bird cherry-oat aphids on potted barley plants in 2015 and 2016. Barley pots with 12 bird cherry-oat aphids were placed in two types of fallow strips ( $\mathrm{W}=$ wildflower strip, $\mathrm{G}=$ grass strip) and in the barley field between two opposite strips at 6,12 and 50-m distances from the strips (Fig. 1). 
W/G $50 \mathrm{~m}$ indicate the position in the middle of the barley field at $50-\mathrm{m}$ distance from both fallow strip types. Error bars indicate \pm one standard error.

Fig. 4. Mean numbers of ground dwelling predatory arthropods in pitfall traps $(\mathrm{n}=32)$ in 2014-2016. The traps were placed in perennial fallow strips $(\mathrm{W}=$ wildflower strip, $\mathrm{G}=$ grass strip) and at 6-m distance from the strips in barley field. The traps were emptied every seven days for eight weeks. Date is the starting date of a trapping period. Arrows show the dates in 2015 and 2016 when aphids on potted barley plants were introduced to the fields. Error bars indicate \pm one standard error.

Fig. 5. Mean catches of aphidophagous predator groups in pitfall traps $(n=32)$ in 2014-2016. The traps were placed in perennial fallow strips $(\mathrm{W}=$ wildflower strip, $\mathrm{G}=$ grass strip) and at 6-m distance from the strips in barley field. Error bars indicate one standard error. 
Fig. 1
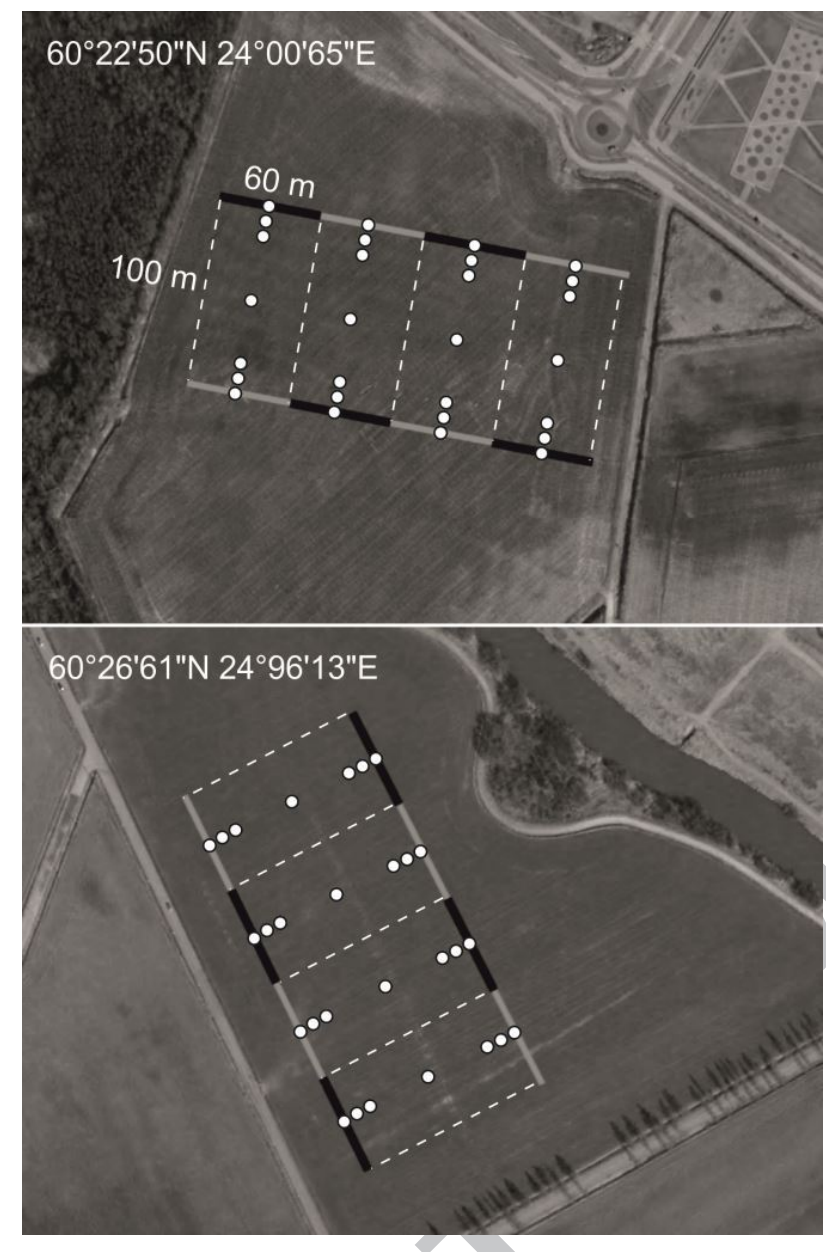
Fig. 2

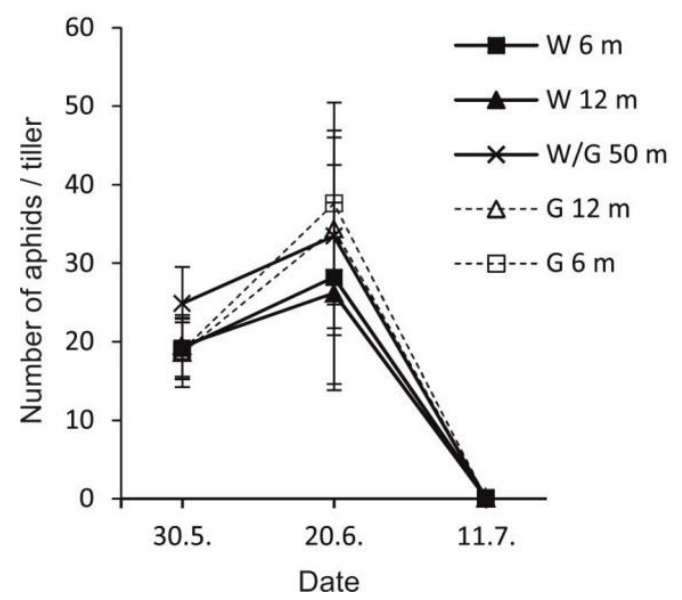


Fig. 3
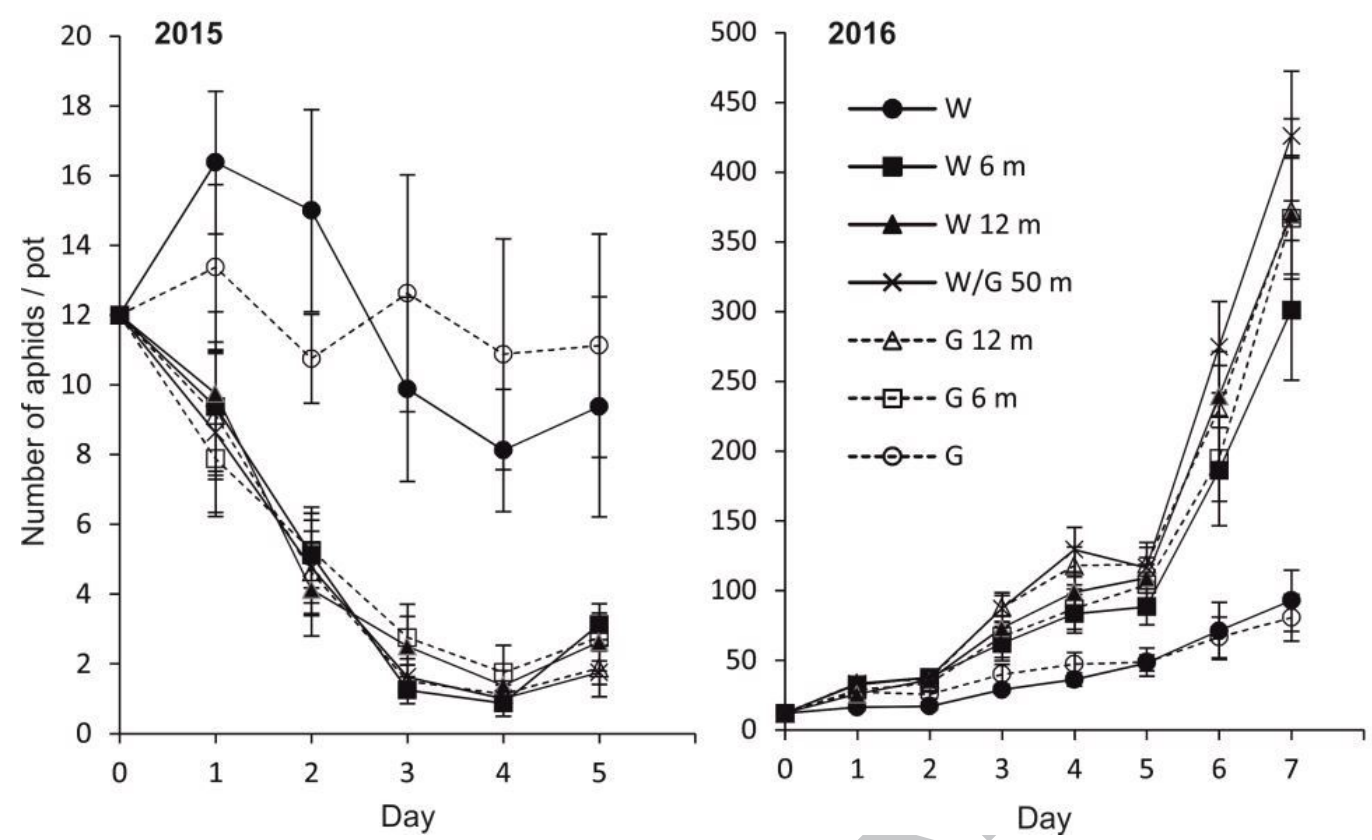
Fig. 4
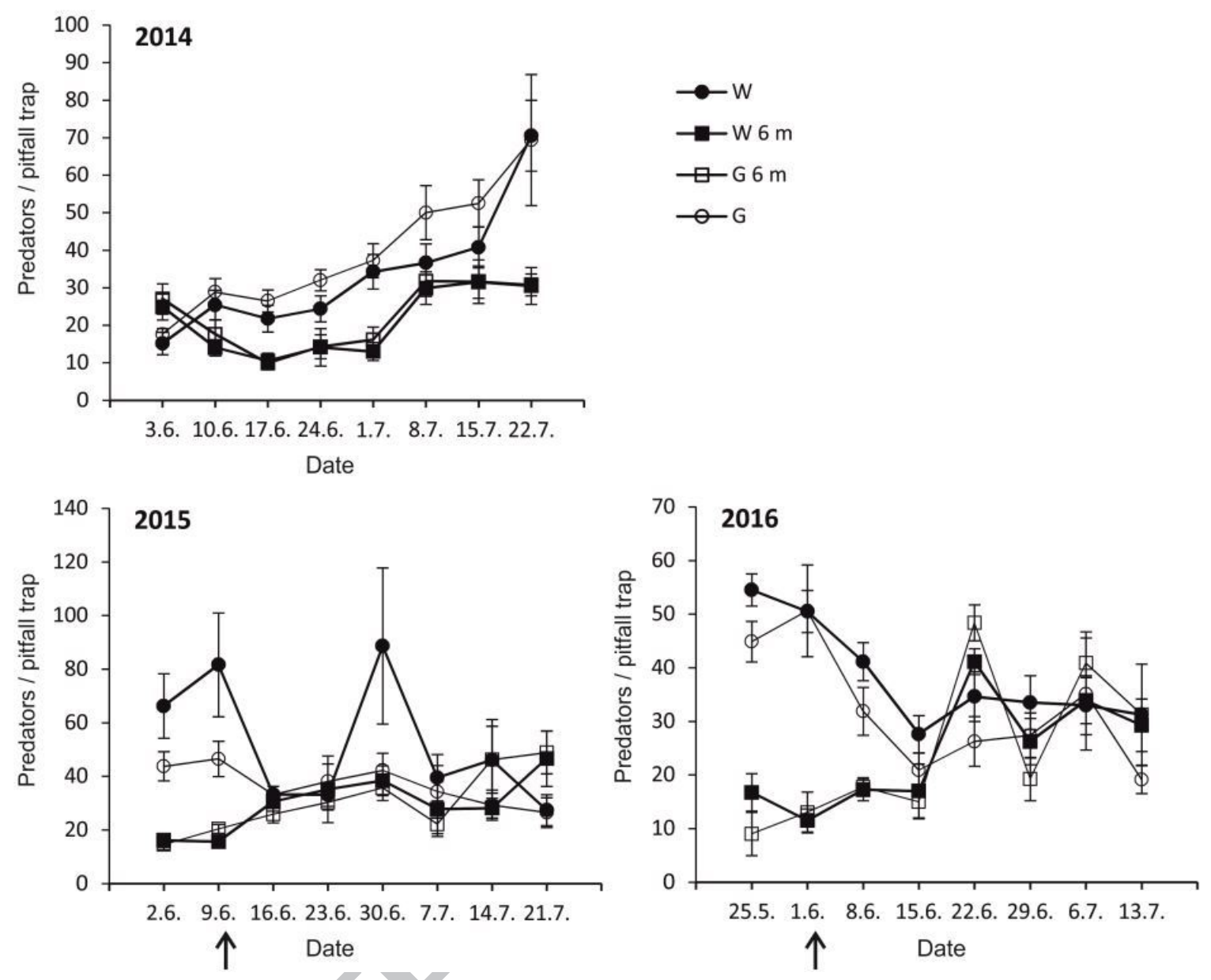
Fig. 5
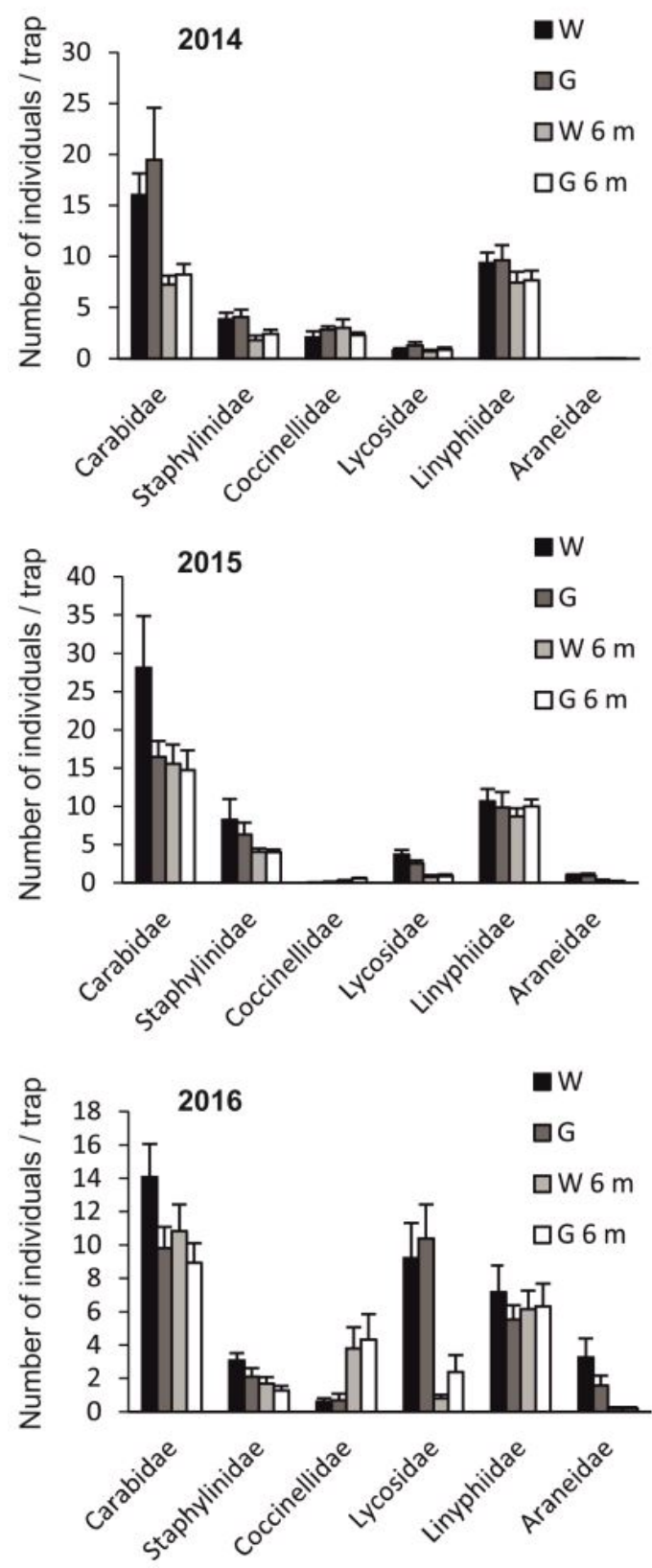


\section{Appendices}

Table A.1 Results of Tukey's pairwise post-hoc tests comparing the number of aphidophagous predator groups in pitfall traps $(\mathrm{n}=32)$ placed in two types of perennial fallow strips and at 6-m distance from the strips in barley field. The first column shows the positions to which the positions of the second column were compared to. Years 2014-2016 were analyzed separately.

\begin{tabular}{|c|c|c|c|c|c|c|c|}
\hline \multirow[t]{2}{*}{ Carabidae } & & \multicolumn{4}{|l|}{2014} & \multicolumn{2}{|l|}{2016} \\
\hline & & Estimate & $\mathrm{p}$ & Estimate & $\mathrm{p}$ & Estimate & $\mathrm{p}$ \\
\hline \multirow[t]{4}{*}{ Wildflower } & Grass & 0.04378 & ns & -0.38478 & ns & -0.3558 & ns \\
\hline & Wildflow & & & & & & \\
\hline & $6 \mathrm{~m}$ & -0.83976 & $* *$ & -0.45151 & ns & -0.27639 & ns \\
\hline & Grass 6 & -0.47898 & ns & -0.5256 & ns & -0.46852 & $* *$ \\
\hline \multirow{3}{*}{ Grass } & & & & & & & \\
\hline & & & $* *$ & -0.06672 & $\mathrm{~ns}$ & 0.07941 & ns \\
\hline & Grass $6 \mathrm{~m}$ & -0.52276 & ns & -0.14082 & ns & -0.11272 & ns \\
\hline & Gra & 036078 & $\mathrm{~ns}$ & -00741 & ns & -0 19213 & ns \\
\hline \multirow[t]{2}{*}{ Staphylinidae } & & 2014 & & 2015 & & 2016 & \\
\hline & & Estimate & $\mathrm{p}$ & Estimate & $\mathrm{p}$ & Estimate & $\mathrm{p}$ \\
\hline \multirow[t]{4}{*}{ Wildflower } & Grass & 0.04378 & ns & -0.14829 & ns & -0.4807 & ns \\
\hline & $\begin{array}{l}\text { Wildflower } \\
6 \mathrm{~m}\end{array}$ & -0 83976 & $* *$ & -033 & $n c$ & - 7102 & ** \\
\hline & Grass $6 \mathrm{~m}$ & -0.47898 & ns & -0.348 & ns & $\begin{array}{l}-0.7102 \\
-0.9245\end{array}$ & $* * *$ \\
\hline & Wildflower & & & & & & \\
\hline \multirow{2}{*}{ Grass } & $6 \mathrm{~m}$ & -0.88354 & $* * *$ & -0.22433 & ns & -0.2295 & ns \\
\hline & Grass $6 \mathrm{~m}$ & -0.52276 & ns & -0.19971 & ns & -0.4438 & ns \\
\hline $\begin{array}{l}\text { Wildflower } 6 \\
\text { m }\end{array}$ & Grass $6 \mathrm{~m}$ & 0.36078 & ns & 0.02462 & ns & -0.2143 & ns \\
\hline \multirow[t]{2}{*}{ Coccinellidae } & & 2014 & & 2015 & & 2016 & \\
\hline & & Estimate & $\mathrm{p}$ & Estimate & $\mathrm{p}$ & Estimate & $\mathrm{p}$ \\
\hline \multirow[t]{2}{*}{ Wildflower } & Grass & -0.00936 & ns & 0.4504 & ns & -0.25021 & $\mathrm{~ns}$ \\
\hline & $\begin{array}{l}\text { Wildflower } \\
6 \mathrm{~m}\end{array}$ & -0.26652 & ns & 1.7713 & ns & 1.698148 & $* *$ \\
\hline
\end{tabular}




\begin{tabular}{|c|c|c|c|c|c|c|c|}
\hline \multirow{3}{*}{ Grass } & $\begin{array}{l}\text { Grass } 6 \text { m } \\
\text { Wildflower }\end{array}$ & -0.22451 & ns & 2.6513 & $* *$ & 1.688446 & $* *$ \\
\hline & $6 \mathrm{~m}$ & -0.25716 & ns & 1.3209 & ns & 1.948358 & $* * *$ \\
\hline & Grass $6 \mathrm{~m}$ & -0.21515 & ns & 2.2009 & $*$ & 1.938656 & $* * *$ \\
\hline $\begin{array}{l}\text { Wildflower } 6 \\
\text { m }\end{array}$ & Grass $6 \mathrm{~m}$ & 0.042012 & $\mathrm{~ns}$ & 0.88 & $\mathrm{~ns}$ & -0.0097 & nS \\
\hline \multirow[t]{2}{*}{ Lycosidae } & & 2014 & & 2015 & & 2016 & 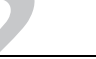 \\
\hline & & Estimate & $\mathrm{p}$ & Estimate & $\mathrm{p}$ & Estimate & $\mathrm{p}$ \\
\hline \multirow[t]{3}{*}{ Wildflower } & $\begin{array}{l}\text { Grass } \\
\text { Wildflower }\end{array}$ & 0.41618 & ns & -0.3794 & ns & 0.2097 & ns \\
\hline & $6 \mathrm{~m}$ & 0.01418 & ns & -1.7426 & $* * *$ & 4908 & $* * *$ \\
\hline & $\begin{array}{l}\text { Grass } 6 \mathrm{~m} \\
\text { Wildflower }\end{array}$ & 0.10544 & $\mathrm{~ns}$ & -1.5514 & & & $* * *$ \\
\hline \multirow[t]{2}{*}{ Grass } & $6 \mathrm{~m}$ & -0.402 & $\mathrm{~ns}$ & -1.3632 & $* * *$ & -2.7005 & $* * *$ \\
\hline & Grass $6 \mathrm{~m}$ & -0.31075 & $\mathrm{~ns}$ & -1.172 & $* * *$ & -1.9297 & $* * *$ \\
\hline $\begin{array}{l}\text { Wildflower } 6 \\
\mathrm{~m}\end{array}$ & Grass $6 \mathrm{~m}$ & 0.09125 & ns & 0.1912 & ns & 0.7708 & ns \\
\hline \multirow[t]{2}{*}{ Linyphiidae } & & 2014 & & 2015 & & 2016 & \\
\hline & & Estimate & $\mathrm{p}^{\prime}$ & Estimate & $\mathrm{p}$ & Estimate & $\mathrm{p}$ \\
\hline \multirow[t]{3}{*}{ Wildflower } & $\begin{array}{l}\text { Grass } \\
\text { Wildflower }\end{array}$ & -0.00936 & ns & -0.11439 & $\mathrm{~ns}$ & -0.21404 & ns \\
\hline & $6 \mathrm{~m}$ & -0.26652 & $\mathrm{~ns}$ & -0.1602 & ns & -0.10218 & ns \\
\hline & Grass & 451 & $\mathrm{~ns}$ & 0.002472 & ns & -0.17612 & ns \\
\hline \multirow[t]{2}{*}{ Grass } & $6 \mathrm{~m}$ & -0.25716 & ns & -0.04581 & ns & 0.11185 & ns \\
\hline & Grass 6 m & -0.21515 & ns & 0.116861 & ns & 0.03792 & ns \\
\hline $\begin{array}{l}\text { Wildflower } 6 \\
\text { m }\end{array}$ & $\mathrm{Gr}$ & 0.042012 & $\mathrm{~ns}$ & 0.162674 & ns & -0.07393 & ns \\
\hline \multirow[t]{2}{*}{ Araneidae } & & 2014 & & 2015 & & 2016 & \\
\hline & & Estimate & $\mathrm{p}$ & Estimate & $\mathrm{p}$ & Estimate & $\mathrm{p}$ \\
\hline \multirow[t]{4}{*}{ Wildflower } & $\begin{array}{l}\text { Grass } \\
\text { Wildflower }\end{array}$ & - & - & -0.22875 & $* * *$ & -0.7453 & $* *$ \\
\hline & $6 \mathrm{~m}$ & - & - & -1.53404 & $* * *$ & -2.87363 & $* * *$ \\
\hline & Grass 6 m & - & - & -2.00563 & $* * *$ & -2.87873 & $* * *$ \\
\hline & Wildflower & & & & & & \\
\hline \multirow{2}{*}{ Grass } & $6 \mathrm{~m}$ & - & - & -1.30529 & $* * *$ & -2.12833 & $* * *$ \\
\hline & Grass 6 m & - & - & -1.77688 & $* * *$ & -2.13344 & $* * *$ \\
\hline $\begin{array}{l}\text { Wildflower } 6 \\
\mathrm{~m}\end{array}$ & Grass $6 \mathrm{~m}$ & - & - & -0.47159 & $* * *$ & -0.0051 & ns \\
\hline
\end{tabular}


Table A.2. List of plant species and their mean coverages (\%) in two types of fallow strips in three years.

\begin{tabular}{|c|c|c|c|c|c|c|}
\hline \multirow[b]{2}{*}{ Species } & \multicolumn{3}{|c|}{ Wildflower strip $(n=8)$} & \multicolumn{3}{|c|}{ Grass strip $(n=8)$} \\
\hline & 2014 & 2015 & 2016 & 2014 & 2015 & 2016 \\
\hline Achillea millefolium & 0.00 & 0.73 & 2.05 & 0.00 & 0.00 & 0.00 \\
\hline Achillea ptarmica & 0.00 & 0.00 & 0.75 & 0.01 & 0.00 & 0.00 \\
\hline Alopecurus geniculatus & 0.01 & 31.50 & 41.00 & 0.00 & 1.70 & 0.00 \\
\hline Anethum graveolens & 0.13 & 0.00 & 0.00 & 0.00 & 0.00 & 0.00 \\
\hline Anthriscus sylvestris & 0.00 & 0.00 & 0.00 & 0.00 & 0.00 & 0.01 \\
\hline Artemisia vulgaris & 0.00 & 0.04 & 0.09 & 0.00 & 0.01 & 0.01 \\
\hline Bidens tripartita & 0.05 & 0.00 & 0.00 & 0.31 & 0.00 & 0.16 \\
\hline Borago officinalis & 0.94 & 0.00 & 0.01 & 0.00 & 0.00 & 0.00 \\
\hline Brassica rapa & 0.55 & 0.02 & 0.00 & 0.27 & 0.02 & 0.00 \\
\hline Bromus inermis & 0.00 & 0.00 & 0.01 & 0.00 & 0.00 & 0.00 \\
\hline Capsella bursa-pastoris & 0.09 & 0.93 & 0.04 & 0.92 & 0.39 & 0.02 \\
\hline Carduus crispus & 0.00 & 0.00 & 0.00 & 0.00 & 0.00 & 0.04 \\
\hline Carum carvi & 0.00 & 0.08 & 0.52 & 0.00 & 0.00 & 0.00 \\
\hline Centaurea cyanus & 5.01 & 1.16 & 0.01 & 0.06 & 0.00 & 0.00 \\
\hline Cerastium fontanum & & 0.02 & 0.00 & 0.02 & 0.00 & 0.00 \\
\hline Chenopodium album & 12.58 & 0.02 & 0.24 & 10.36 & 0.01 & 0.46 \\
\hline Cirsium arvense & 0.20 & 7.07 & 4.06 & 3.05 & 4.74 & 2.56 \\
\hline Cirsium palustre & 0.00 & 0.00 & 0.00 & 0.00 & 0.01 & 0.00 \\
\hline Cirsium vulgaris & 0.00 & 0.16 & 0.00 & 0.00 & 0.08 & 0.00 \\
\hline Elymus repens & 0.00 & 0.00 & 1.73 & 0.04 & 0.00 & 0.16 \\
\hline Epilobium adenocaulon & 0.01 & 0.03 & 0.01 & 0.01 & 0.01 & 0.00 \\
\hline Equisetum arvense & 16.25 & 16.50 & 19.25 & 14.00 & 11.00 & 12.50 \\
\hline Erysimum cheiranthoides & 0.02 & 0.00 & 0.01 & 0.02 & 0.01 & 0.01 \\
\hline Fagopyrum esculentum & 2.38 & 0.01 & 0.00 & 0.00 & 0.00 & 0.00 \\
\hline Fallopia convulvulus & 0.10 & 0.02 & 0.01 & 0.50 & 0.02 & 0.01 \\
\hline Festuca arundinacea and $F$. & & & & & & \\
\hline pratensis & 0.00 & 0.00 & 0.00 & 0.00 & 46.25 & 50.50 \\
\hline Festuca trachyphylla & 0.00 & 15.83 & 24.38 & 0.00 & 0.00 & 0.00 \\
\hline Fumaria officinalis & 0.44 & 0.02 & 0.00 & 0.43 & 0.02 & 0.00 \\
\hline Galeopsis bifida & 9.00 & 0.95 & 0.00 & 4.70 & 0.05 & 0.04 \\
\hline Galeopsis speciosa & 3.47 & 0.92 & 0.01 & 1.17 & 0.01 & 0.01 \\
\hline Galium palustre & 0.00 & 0.00 & 0.01 & 0.00 & 0.01 & 0.01 \\
\hline Galium spurium & 0.00 & 0.00 & 0.02 & 0.00 & 0.00 & 0.01 \\
\hline Galium uliginosum & 0.14 & 0.03 & 0.00 & 3.23 & 0.03 & 0.00 \\
\hline Gnaphalium uliginosum & 0.05 & 0.01 & 0.00 & 0.42 & 0.00 & 0.01 \\
\hline
\end{tabular}




\begin{tabular}{|c|c|c|c|c|c|c|}
\hline Lamium album & 0.00 & 0.00 & 0.00 & 0.00 & 0.01 & 0.00 \\
\hline Lapsana communis & 0.44 & 0.24 & 0.01 & 0.33 & 0.06 & 0.04 \\
\hline Lathyrus pratensis & 0.00 & 0.00 & 0.04 & 0.00 & 0.00 & 0.00 \\
\hline Leucanthemum vulgare & 0.00 & 0.78 & 2.07 & 0.00 & 0.00 & 0.00 \\
\hline Linaria vulgaris & 0.00 & 0.00 & 0.01 & 0.00 & 0.00 & 0.00 \\
\hline Linum usitatissimum & 0.01 & 0.00 & 0.00 & 0.00 & 0.00 & 0.00 \\
\hline Lolium perenne & 0.00 & 0.75 & 0.01 & 0.00 & 9.75 & 6.04 \\
\hline Lotus corniculatus & 0.00 & 0.00 & 0.00 & 0.00 & 0.00 & 0.01 \\
\hline Matricaria matricarioides & 0.05 & 0.00 & 0.00 & 0.91 & 0.00 & 0.01 \\
\hline Medicago sativa & 0.00 & 0.00 & 0.00 & 0.00 & 0.00 & 0.01 \\
\hline Myosotis arvensis & 0.02 & 3.70 & 0.00 & 0.03 & 0.06 & 0.00 \\
\hline Mentha arvensis & 0.00 & 0.01 & 0.00 & 0.00 & 0.00 & 0.00 \\
\hline Papaver rhoeas & 0.00 & 0.00 & 0.00 & 0.01 & 0.00 & 0.00 \\
\hline Persicaria lapathifolia & 0.37 & 0.00 & 0.01 & 3.95 & 0.00 & 0.05 \\
\hline Phacelia tanacetifolia & 50.75 & 1.34 & 0.16 & 0.02 & 0.00 & 0.00 \\
\hline Phleum pratense & 3.42 & 0.00 & 0.01 & 37.70 & 43.50 & 54.75 \\
\hline Plantago major & 1.14 & 4.06 & 1.16 & 0.05 & 0.05 & 0.00 \\
\hline Poa pratensis & 0.01 & 0.01 & 0.91 & 0.00 & 0.00 & 0.00 \\
\hline Polygonum aviculare & 0.19 & 0.02 & 0.01 & 0.15 & 0.01 & 0.05 \\
\hline Ranunculus repens & 0.00 & 0.02 & 0.23 & 0.01 & 0.17 & 10.30 \\
\hline Ranunculus sceleratus & 0.02 & 0.00 & 0.00 & 0.01 & 0.00 & 0.00 \\
\hline Rorippa palustris & 0.00 & 5.25 & 0.05 & 0.00 & 0.40 & 0.04 \\
\hline Rumex longifolius & & 0.02 & 0.04 & 0.00 & 0.00 & 0.00 \\
\hline Senecio vulgaris & 0.0 & 0.00 & 0.00 & 0.01 & 0.00 & 0.00 \\
\hline Solanum dulcama & 0.00 & 0.01 & 0.00 & 0.00 & 0.00 & 0.00 \\
\hline Sonchus arvensis & 8.00 & 9.75 & 18.31 & 14.61 & 16.30 & 6.40 \\
\hline Sonchus asper & 0.20 & 0.00 & 0.00 & 0.42 & 0.00 & 0.00 \\
\hline Sonchus oleraceus & 0.01 & 0.00 & 0.00 & 0.02 & 0.00 & 0.04 \\
\hline Spergula arvensis & 0.18 & 0.00 & 0.00 & 0.40 & 0.00 & 0.00 \\
\hline Stachys palustris & 0.00 & 0.00 & 0.00 & 0.16 & 0.01 & 0.00 \\
\hline Stellaria graminea & 0.01 & 0.00 & 0.00 & 0.00 & 0.00 & 0.00 \\
\hline Stellaria media & 0.93 & 0.05 & 0.41 & 3.20 & 0.02 & 0.53 \\
\hline Taraxacum sp. & 0.01 & 0.35 & 6.02 & 0.01 & 0.02 & 1.55 \\
\hline Thlaspi arvense & 0.01 & 0.02 & 0.00 & 0.02 & 0.02 & 0.00 \\
\hline Trifolium hybridum & 0.01 & 0.21 & 0.79 & 0.00 & 0.02 & 0.00 \\
\hline Trifolium pratense & 0.01 & 0.00 & 0.00 & 0.02 & 0.03 & 0.01 \\
\hline Trifolium repens & 0.02 & 0.05 & 0.35 & 0.00 & 0.01 & 0.00 \\
\hline \multicolumn{7}{|l|}{ Tripleurospermum } \\
\hline inodorum & 3.27 & 15.50 & 0.44 & 6.84 & 0.15 & 0.40 \\
\hline Urtica dioica & 0.00 & 0.01 & 0.00 & 0.00 & 0.00 & 0.00 \\
\hline Vicia cracca & 0.05 & 0.70 & 1.88 & 0.16 & 0.06 & 0.20 \\
\hline Vicia hirsuta & 0.05 & 0.00 & 0.00 & 0.08 & 0.00 & 0.00 \\
\hline גם & 373 & 0 & 0 & 0 & 000 & 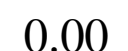 \\
\hline
\end{tabular}




\section{Highlights}

- The effects of grass and wildflower strips on biological control were compared.

- Wildflower strips performed slightly better than grass strips.

- The proximity of the both strip types reduced aphid pressure during aphid outbreak.

- Epigeal predators moved from the strips to the fields before the aphid peaked.

- Predator communities differed between grass and wildflower strips. 